\title{
Northern Shrimp (Pandalus borealis) Recruitment in West Greenland Waters Part I. Distribution of Pandalus Shrimp Larvae in Relation to Hydrography and Plankton
}

\author{
S.A. Pedersen and L. Storm \\ Greenland Institute of Natural Resources/Danish Institute for Fisheries Research \\ Department of Marine Ecology and Aquaculture \\ Kavalergården 6, DK-2920 Charlottenlund, Denmark \\ and \\ C. S. Simonsen \\ Greenland Institute of Natural Resources \\ P.O. Box 570, 3900 Nuuk, Greenland
}

\begin{abstract}
Plankton samples and oceanographic data were obtained during transect studies across fishing banks over the West Greenland shelf areas in June 1999, May, and July 2000. The hypothesis that larval shrimp are linked to the behaviour of hydrographic fronts was tested by determining whether larval shrimp abundance was linked to plankton distributions, species composition and primary productivity. We found six pelagic developmental stages (ZI-ZVI) in two species of Pandalus larvae. P. borealis was the most abundant species in all stages from ZII to ZVI. The smaller $P$. montagui larvae were slightly more advanced in development than $P$. borealis, suggesting later hatching or longer development time for P. borealis larvae. In May, high concentrations of newly hatched ZI larvae were caught near the coast and at fjord stations. In June and July, larvae in development stage ZIV dominated the catches. The two species showed minor differences in larval distribution across banks and between transects, indicating a wide larval dispersal and a relatively short hatching period. We found no relationship between indices of larval shrimp abundance and the T-S characteristics of water masses, chlorophyll $a$ concentrations or zooplankton abundance (species, groups or sizes classes). Data from two satellite tracked SVP buoys was used to calculate a net northward drift of about $3.1 \mathrm{~km} \mathrm{~d}^{-1}$ or $200-400 \mathrm{~km}$ during the pelagic life of a larval cohort. Difference in year-class strength was attributed to differences in the environmental conditions and the larval transport patterns. We suggest that coupled physical-biological models should be developed to investigate the climatic impact on distribution and recruitment variability of northern shrimp in West Greenland waters.
\end{abstract}

Key words: distribution, Greenland, larval shrimp, Pandalus, plankton, recruitment

\section{Introduction}

During the last part of the $20^{\text {th }}$ century the fishery for northern shrimp (Pandalus borealis Krøyer, 1838) has been the most important fishery off Greenland. Although subjected to a large fishery, the West Greenland shrimp population has shown increasing growth and recruitment since 1997 (Carlsson and Kanneworff, MS 1999; Siegstad, MS 2000). Year-class strength of shrimps is most likely established during the pelagic larval life driven by environmental changes (Shumway et al., 1985; Tande et al., 1994; Rasmussen and Tande, 1995; Parsons and Colbourne, 2000;
Anderson, 2000). In a study of northern shrimp in the Gulf of St. Lawrence, Ouellet et al. (1995) proposed that larval survival and recruitment to the shrimp stocks are influenced by factors affecting stratification and mixing in the water column, i.e. buoyancy fluxes, through control of phytoplankton and copepod production. In general the hydrographic and biological processes behind observed variability in recruitment to shrimp stocks in West Greenland are poorly understood (Hvingel and Savard, 1997; Pedersen, 1998). More studies are required to identify the nursery grounds and ontogenetic movements of the shrimp found on each of the fishing grounds in 
the northwest Atlantic (Lilly et al., 1998). The increase in the shrimp biomass in recent years can most likely not be attributed solely to changes in climate (Pedersen and Rice, 2002). Drastic declines in the West Greenland fish stocks have reduced shrimp predation, and by-catch of fish in the shrimp fishery have contributed to keep the predator pressure on the shrimp population low (Buch et al., 2002).

Hydrographic conditions along the west coast of Greenland are determined by the mixture of water from the East Greenland Polar Current and Atlantic water from the Irminger Current forming the West Greenland Current. The exchange of water between the polar and temperate regions affects the marine productivity in the shelf areas, and changes in the global circulation system have major impacts on species distributions and fisheries yield (Pedersen and Smidt, 2000; Pedersen and Rice, 2002; Buch et al., 2002). Historic observations show relationships between climate variability and changes in the West Greenland fisheries, which should allow the incorporation of environmental information in prediction models for fish stock recruitment and abundance (Buch et al., 2002). Successful predictive modelling requires a comprehensive understanding of the processes involved. Understanding the links between hydrographic features and the marine pelagic food web during the productive period are keys to understand changes in recruitment of fish and shellfish in marine ecosystems (e.g. Cushing, 1989; Kiørboe, 1993; Mann and Lazier, 1996; Horwood et al., 2000; Anderson, 2000; Hansen et al., 2002).

Hydrographic fronts (e.g. regions of transition between mixed and stratified water masses) surrounding banks may have profound effects on plankton distribution patterns, and larval fish and shrimp recruitment (e.g. Taggart et al., 1989; Franks, 1992; Munk et al., 1995; Lochmann et al., 1997; Reiss et al., 2000; Lough and Manning, 2001). Associations between abundances of various fish and shrimp larvae, and hydrographic gradients over the West Greenland shelf area between 1950-1984, indicate that it may be possible to relate interannual variation in larval abundance and subsequent recruitment of year classes to the distribution of water masses with varying characteristics (Pedersen and Rice, 2002).

We collected plankton and hydrographic data from the West Greenland shelf in June 1999, May and July 2000 in order to describe the marine pelagic food web, its structure and dependence upon hydrographic fronts at and around the shelf banks. The present paper reports on (1) distribution and abundance indices of larval shrimp development stages, (2) larval distribution in relation to hydrography and biological habitat characteristics, and (3) current tracking, hydrographic features, and possible plankton drift. A companion paper, Pedersen and Storm (2002), reports on lipid content and trophic relationships of the shrimp larvae.

\section{Materials and Methods}

\section{Study area and sampling}

Sampling for Pandalus spp. shrimp larvae was carried out in June 1999, May 2000, and July 2000 between $63^{\circ} 50^{\prime} \mathrm{N}$ and $66^{\circ} 50^{\prime} \mathrm{N}$ on the West Greenland shelf with the Greenlandic research vessels Adolf Jensen and Paamiut (Fig. 1; Table 1). Stations were spaced at approximately 4,8 and $15 \mathrm{~km}$ along transects across shelf areas. The distance between stations was less where hydrographic fronts enhancing productivity and larval aggregation are likely to occur. In May and June, sampling was performed at stations along transects crossing Fyllas- and Sukkertop Bank. In July, sampling was carried further north to include stations along transects crossing Lille- and Store Hellefisk Bank using the two research vessels at the same time. A large number of off-transect stations were sampled in June and July, and 6 coast/fjord stations were sampled in May in the inshore Nuuk-area (Fig. 1; Fig. 2a,b).

The sampling gear used was: (1) MIK plankton sampler ( $2 \mathrm{~m}$ diameter) equipped with a $16 \mathrm{~m}$ long nylon monofile net of $1 \mathrm{~mm}$ mesh size (Munk, MS 1993), and (2) Bongo plankton sampler $(0.61 \mathrm{~m}$ diameter) equipped with two $0.5 \mathrm{~mm}$ nylon monofil nets (Table 1). At every station larval shrimp samples were obtained between 8 and 21 o'clock (local time) using depth integrated oblique (diagonal) tows to near the bottom or to a maximum of $200 \mathrm{~m}$ at a towing speed of 3 knots. The towing time was $\sim 30$ minutes for tows to the maximum depth, $200 \mathrm{~m}$. However, during the cruise with Paamiut in July most tows were performed at night and the maximum towing depth was $90 \mathrm{~m}$. The volume filtered was determined using General Oceanics flowmeters.

On each station vertical profiles of temperature, salinity, and density were obtained with a Sea-bird 


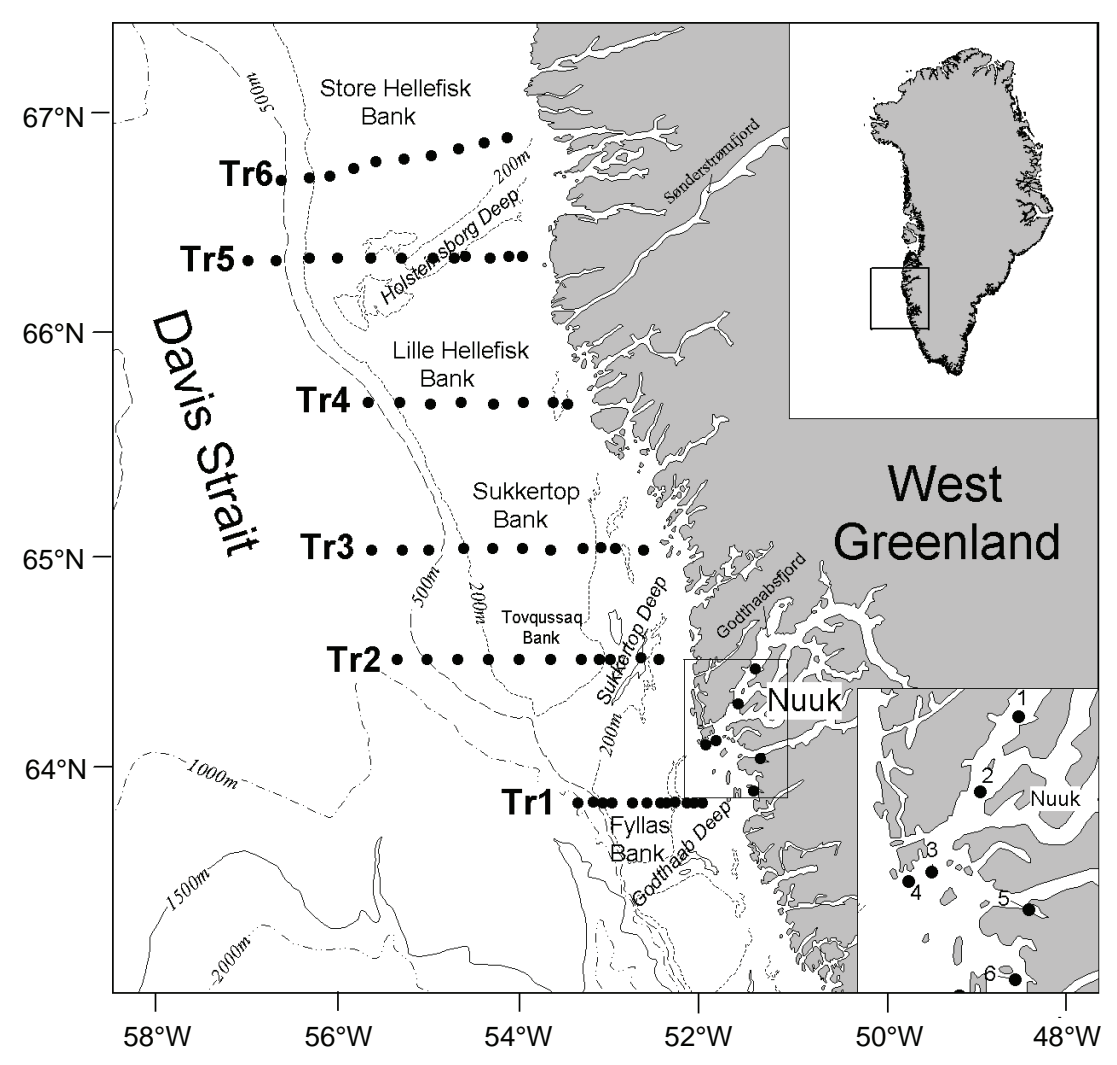

Fig. 1. Bathymetric chart of the West Greenland Shelf study area, with indication of sampling stations along 6 cross-shelf transects ( $\operatorname{Tr} 1-$ Tr6). Transects were sampled as follows: $\operatorname{Tr} 1$ and $\operatorname{Tr} 3$ in May 2000, Tr2-Tr3 in June 1999, Tr1-Tr6 in July 2000. Six inshore sampling stations were sampled in May 2000, only.

TABLE 1. Sampling data from the four cruises. May and July sampling was conducted in 2000, whereas June sampling was conducted in 1999.

\begin{tabular}{llll}
\hline \hline Period & Reseach Vessel & Transect & Gear (Diameter; mesh size) \\
\hline 12-21 May 2000 & RV Adolf Jensen & 1,3 & Bongo $(0.6 \mathrm{~m} ; 500 \mu \mathrm{m})$ \\
21-30 June 1999 & RV Adolf Jensen & 2,3 & MIK $(2 \mathrm{~m} ; 1000 \mu \mathrm{m})$ \\
11-23 July 2000 & RV Adolf Jensen & $1,4,5$ & MIK $(2 \mathrm{~m} ; 1000 \mu \mathrm{m})$ \\
12-27 July 2000 & RV Paamiut & $2,3,6,7,8$ & Bongo $(0.6 \mathrm{~m} ; 500 \mu \mathrm{m})$ \\
\hline
\end{tabular}

SBE 9-011 sealogger CTD. Fluorescence was measured with a HydroScat 2 fluorometer from HOBILabs, except during the cruise with Paamiut in July. The fluorescence was calibrated against fluorometrically determined chlorophyll $a$ content in water samples collected on selected stations in May and June (Poulsen and Reuss, 2002). The chlorophyll $a$ concentrations were used as indices of phytoplankton biomass.
Depth integrated micro- and mesozooplankton samples of the upper $100 \mathrm{~m}$ (or $2 \mathrm{~m}$ above bottom at shallower stations) were obtained on at least every second station. In June and in July with Paamiut, these samples were collected from one vertical haul with a WP-2 net $(0.58 \mathrm{~m}$ diameter and $50 \mu \mathrm{m}$ mesh size) retrieved at $10 \mathrm{~m} \mathrm{~min}^{-1}$ assuming $100 \%$ filtration efficiency. In May and in July with Adolf Jensen, samples were collected using a submersible pump (900 
$1 \mathrm{~min}^{-1}$, HOMA-H500, DIFRES-design) equipped with a conical net of $50 \mu \mathrm{m}$ mesh size. The pump was lowered to max sampling depth of the MIK or Bongo plankton sampler (100 m in May; $200 \mathrm{~m}$ in June and July with Adolf Jensen) started and retrieved to the surface at $10 \mathrm{~m} \mathrm{~min}^{-1}$. All zooplankton samples (MIK, Bongo, WP-2 and pump) were preserved in 4-8\% buffered formalin in seawater.

\section{Species, stage, size, and abundance of larval shrimp and zooplankton}

Pandalus shrimp larvae were sorted from the MIK and Bongo zooplankton samples in the laboratory. Samples containing more than 400 shrimp larvae were split in order to count a minimum of about 200 larvae. From each sample a subsample of about 40 shrimp larvae were identified to zoeal stage and their carapace length (cl) measured (posterior edge of orbit to mid- dorsal posterior margin of carapace) under a dissecting microscope with an optical micrometer.

Stage identifications of the shrimp larvae were based on Rasmussen (MS 1993) and T. Rasmussen, SEA ECO, Harstad, Norway, pers. comm. Two species of Pandalus shrimp larvae and six zoeal larval stages (ZI-ZVI) were identified for both species: Pandalus borealis (Berkeley, 1930; Haynes, 1979,1985; Squires, 1993; Rasmussen, MS 1993), and Pandalus montagui (Pike and Williamson, 1964; Squires, 1993; Schultze and Anger, 1997). It is difficult to discriminate between these two species morphologically, especially formalin preserved larvae whose pigmentation has disappeared (Pedersen, 1998). However, in the same zoeal stage $P$. borealis $(\mathrm{Pb})$ are larger than $P$. montagui (Pm). Based on Pedersen (1998) and length-frequency
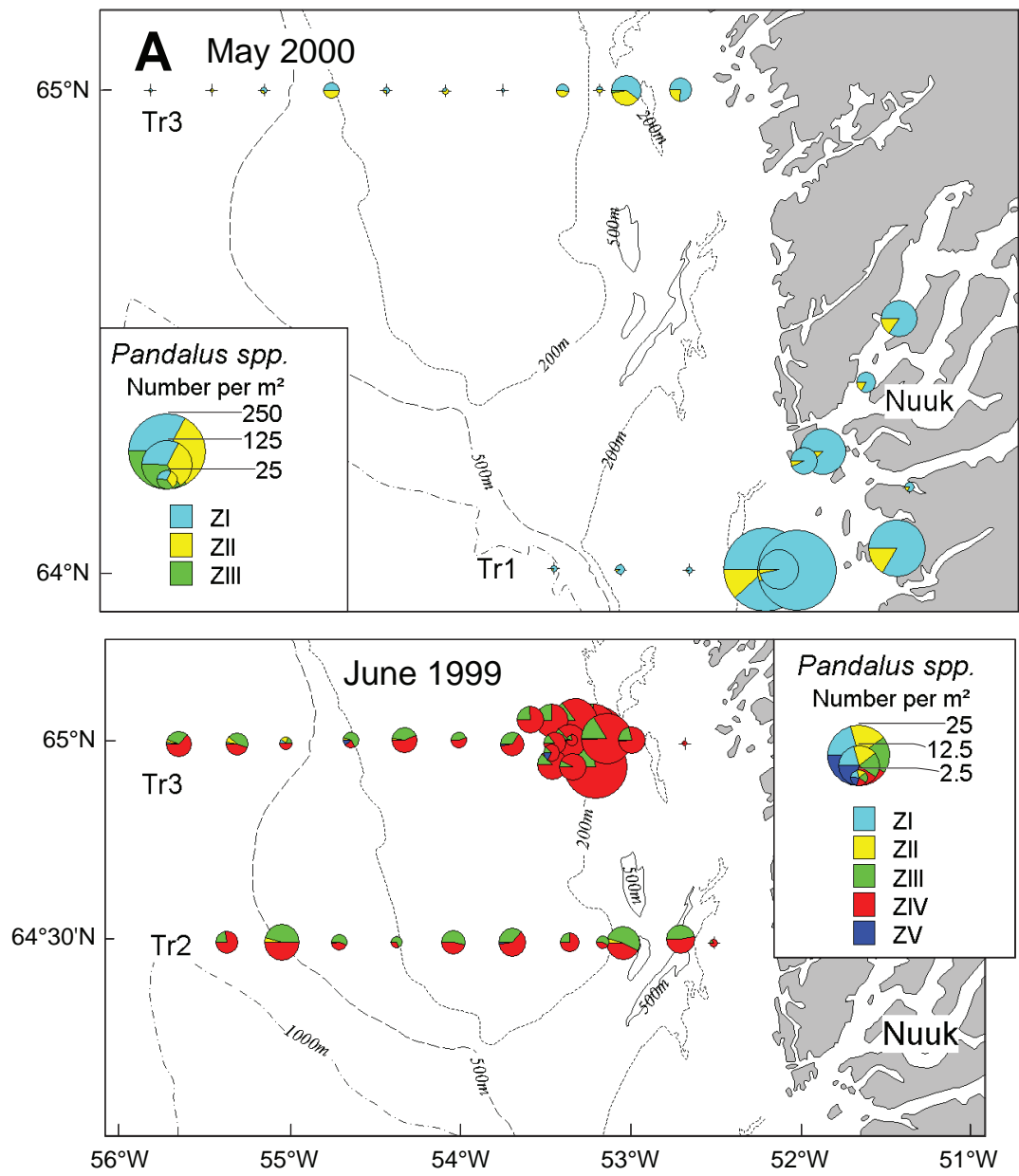

Fig. 2a. Distribution and abundance of larval Pandalus development stages in May 2000 and June 1999. Transects and off transect stations shown. Dot sizes are graduated by square root. 

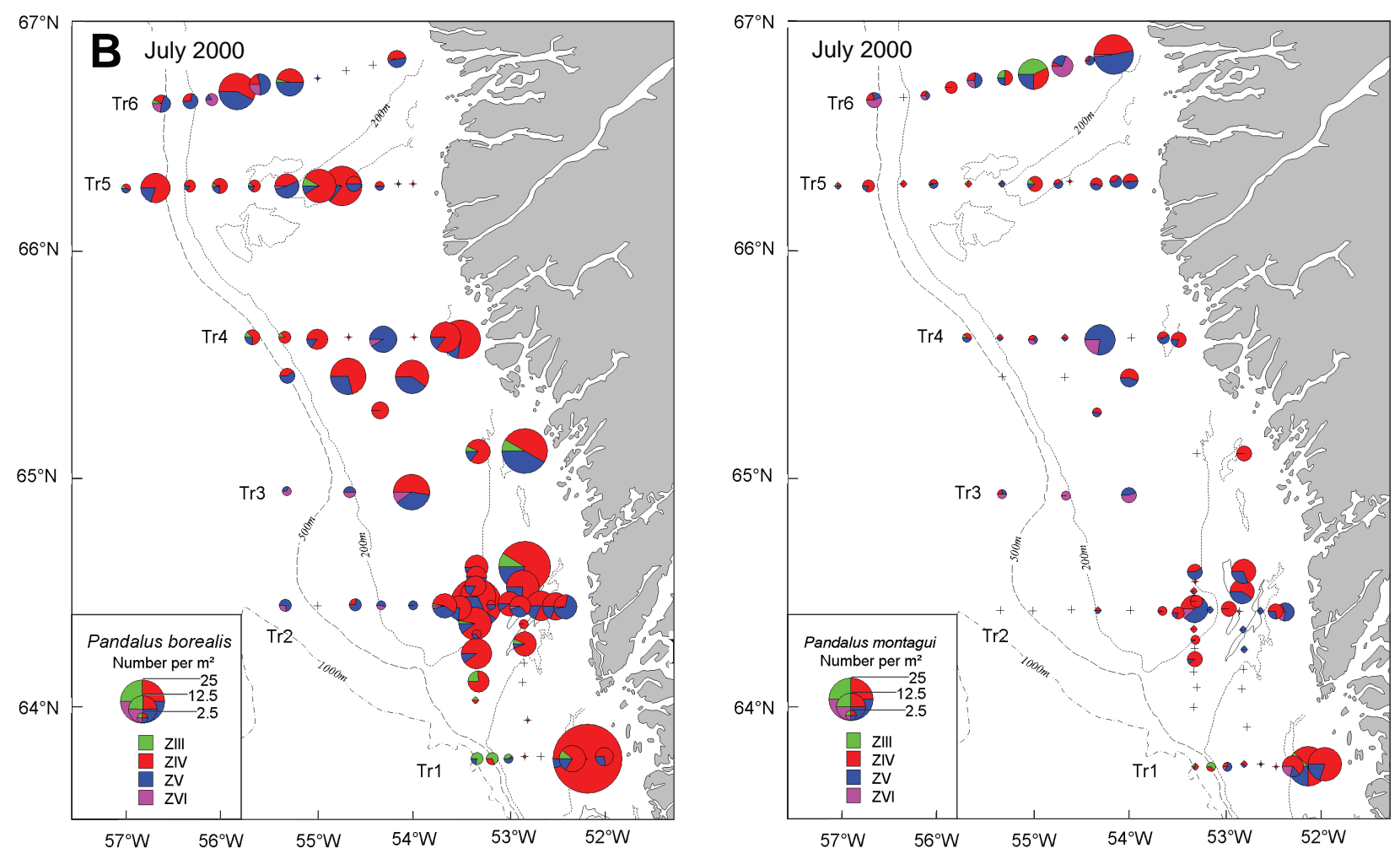

Fig. 2b. Distribution and abundance of larval Pandalus development stages in July 2000. Transects and off transect stations shown. Dot sizes are graduated by square root.

diagrams by stage and station from this study the following size criteria by stage were found to identify and separate the smaller $P$. montagui larvae: Stage ZI: no discrimination; Pm stage ZII: cl $<1.5 \mathrm{~mm}$; Pm stage ZIII: cl $<2.0 \mathrm{~mm}$; Pm stage ZIV: $\mathrm{cl}<2.7$ $\mathrm{mm}$; Pm stage ZV: cl $<3.0 \mathrm{~mm}$; Pm stage ZVI: cl $<3.5 \mathrm{~mm}$. Discrimination between the two species based on fixed size criteria is questionable as different sizes at stage could be caused by genetic or temperature differences during larval development (ecophenotypic effects). However, no genetic differences in $P$. borealis populations from West Greenland have been found. Furthermore laboratory experiments found no significant difference in carapace length, at the same stage, from the effect of different rearing temperatures (Shumway et al., 1985). Therefore, we assume that the size criteria discriminated the two Pandalus species although overlap in the size frequency distributions was seen at some stations (see discussion in Pedersen, 1998).

To identify biotic habitats and abundances of potential food sources of Pandalus larvae, subsamples of micro- and mesozooplankton were sorted and identified to the lowest possible taxon in the laboratory. Each species or taxonomic category was enumerated and length measured. Within each copepodite stage up to 10 specimens were length measured (prosome length). Abundance and length information was used to estimate the copepod biomass as total carbon within taxonomic categories at each sampling station. Length-weight relationships (ashfree dry weight) were obtained from the literature: Calanus (all three species) and Metridia longa from Hirche and Mumm (1992), Acartia spp. and all nauplii from Berggreen et al. (1988), Pseudocalanus sp. from Klein Bretler et al. (1982), while for the smaller taxons Oithona spp., Microcalanus spp., Oncaea spp. and Microsetella spp. the relationship for Oithona spp. in Sabatini and Kiørboe (1994) was used. The carbon content of Calanus spp. stages I to III and the smaller taxons were assumed to be $50 \%$ of dry weight, while a conversion factor of $60 \%$ was used for older stages (Hansen et al., 1994). The shrimp larval biomass as carbon content was estimated from total lipid contents (Pedersen and Storm, 2002) using a relation for brachyuran larvae (Anger and Harms, 1990). 
Abundance and biomass estimates of shrimp larvae and other taxa were standardized to number $\mathrm{m}^{-2}$ of sea surface to sampling depth (e.g. Smith and Richardson, 1977).

\section{Ocean stability and current tracking}

The potential energy $(P)$ of the upper part of the water column was calculated as a measure of the stability of the water column, i.e. the energy input needed to break down stability and homogenise the water column (Pedersen, 1986):

$$
P(z)=-g \int_{0}^{z}\left(\rho_{\mathrm{hom}}-\rho(z)\right) z d z\left(J m^{-2}\right)
$$

where $g$ is the gravitational acceleration $\left(9.82 \mathrm{~m} \mathrm{~s}^{-2}\right)$, $\rho_{\text {hom }}$ is the density $\left(\sigma_{t}\right)$ of the homogenised water column and $\rho(z)$ is the density measured at depth $z$.

Two satellite tracked SVP drift buoys (Technocean, Inc) with drogues of $3.4 \mathrm{~m}^{2}$ at $30 \mathrm{~m}$ were deployed east and west of Fyllas Bank during the May cruise. Positions of the buoys obtained approximately every three hours from the two drifters were used to give information on velocities of prevailing ocean currents and possible plankton drift in the study area. Data from the meteorological station at Nuuk on wind speed and directions every three hours during the study periods were compared to the observed patterns of hydrography and ocean drift.

\section{Data analysis}

Tests for differences between stations and transects of larval shrimp development stages and sizes were performed using multi- and one-way analysis of variance (ANOVA) (SAS, 1985 - GLM procedure). Associations among temperature, salinity, phytoplankton (chlorophyll $a$ ), abundance of copepods, egg, nauplii (indices of copepod productivity), invertebrate larvae, and larval shrimp abundance were tested using Spearman rank correlations.

\section{Results}

Larval Pandalus distributions, stage development, and sizes

In May, highest larval concentrations (30-300 individuals per $\mathrm{m}^{-2}$ ) were found at the coastal stations of $\operatorname{Tr} 1$ and $\operatorname{Tr} 3$ and at stations within the fjords (Fig. 2a). Pandalus larvae were also caught at stations crossing the banks westward, with fewer larvae on the bank in $\operatorname{Tr} 3$ and a slight increase offshore after crossing the bank. The majority of the larvae caught in May were ZI larvae with a trend of higher proportion of ZII larvae on $\operatorname{Tr} 3$ (Fig. 2a). We were unable to separate stage ZI larvae in $P$. borealis and P. montagui. At the fjord stations many ZI larvae were small and apparently newly hatched. Of all ZII larvae $27 \%$ were identified to $P$. borealis, indicating that $P$. borealis lagged behind in development compared to $P$. montagui.

In June, highest larval concentrations ( 20 individuals per $\mathrm{m}^{-2}$ ) were found just east of Sukkertop Bank on $\operatorname{Tr} 3$ and at a few off transect stations (Fig. 2a). At other stations of $\operatorname{Tr} 2$ and $\operatorname{Tr} 3$ larval concentrations were below 10 individuals per $\mathrm{m}^{-2}$ with lowest concentrations at the 2 easternmost transect stations. Most larvae were in ZIII and ZIV, with ZIV generally dominating, especially at stations with highest larval concentrations (Fig. 2a). Of all Pandalus larvae caught $68 \%$ were identified as $P$. borealis. The highest proportions of $P$. montagui were observed on stations closest to the coast and over the shallower parts of the banks. On westernmost stations of $\operatorname{Tr} 2$ and $\operatorname{Tr} 3$ small proportions of ZII larvae were found. Of the ZII larvae $95 \%$ were identified to $P$. borealis, indicating that $P$. montagui was more advanced in development compared to $P$. borealis.

In July, highest larval concentrations (10-35 $\mathrm{m}^{-2}$ ) were found over the banks and in the deep channels between the banks and the coast (Fig. 2b). On the two northern transects, $\operatorname{Tr} 5$ and Tr6, high concentrations were also found at stations west of Store Hellefisk Bank. The species proportion of all Pandalus larvae caught was $71 \%$ P. borealis and $29 \%$ P. montagui. The larvae were in stages ZIII to ZVI, ZIV larvae being dominant in both species. Generally P. borealis and P. montagui in stages ZIV to ZVI showed similar distribution (Fig. 2b, Appendix Fig. 1 and 2). However, along Tr6 $P$. borealis larvae were most abundant on the western deeper stations and $P$. montagui were most abundant on the eastern shallower stations over the bank (Fig. 2b, Appendix / Fig. 1 and 2).

Multi-way ANOVA of zoeal stage by month showed significant $(p<0.05)$ effects of species, station and transect in June and July. There were no clear trends in stage composition (mean stage) between or along transects in either June or July. The mean stage duration was estimated to be about 20 days for both species, assuming peaks in hatching and larval appearance in the plankton in the beginning of May (Fig. 3). Assuming linear growth, the larvae caught in June 1999 appeared to be more advanced in 


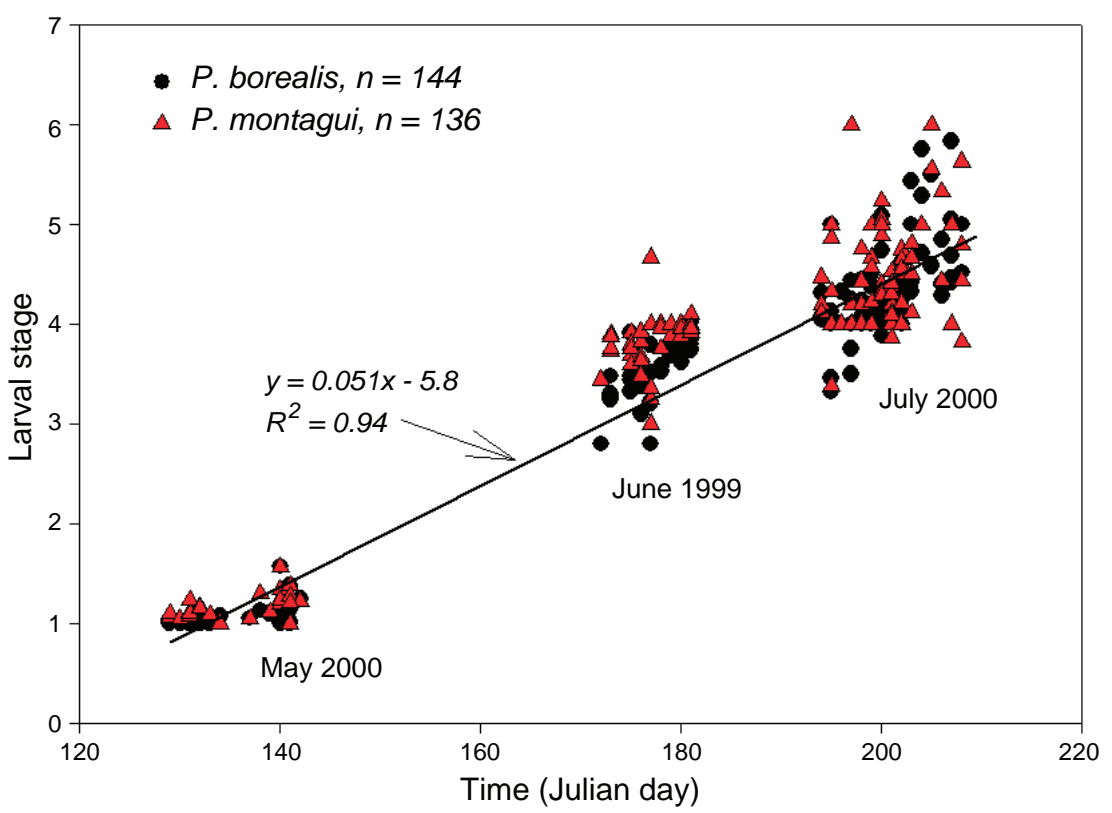

Fig. 3. Mean zoeal stage by station and species as a function of time. All stations May 2000, June 1999, and July 2000.

development compared to the July 2000 larvae. In June 1999, the stage composition of the smaller P. montagui larvae was skewed to slightly more developed larvae compared to $P$. borealis.

In May, ZI and ZII larvae were larger on Tr1 and Tr3 compared to larvae from inshore (fjord and coastal) stations (Table 2a). Although multi-way ANOVA of larval size by species, and stage showed significant $(p<0.05)$ effects of station, and transect, there was no clear trends in mean size (carapace length) between or along transects either in June or July. However, the mean size of $P$. montagui larvae in stage ZIV and ZV showed large variations e.g. ZV larvae from TR1, 5, and 6 in July being significantly smaller than ZIV larvae from $\operatorname{Tr} 2,3$, and 4 (Table 2b). This was partly caused by uncertainty in the determination of larvae to stage/species (e.g. during moulting; moulting larvae occurred at some stations), and partly because exceptional small stage ZIV and ZV larvae occurred at a few stations, these might belong to a different species, Dichelopandalus leptocerus (see remarks p. 276 in Pike and Williamson, 1964).

\section{Hydrography and biological habitats}

From May to July, temperatures in the upper 200 m of the water column over the southwest Greenland shelf Banks (Tr1-3) increased from below zero to above $5^{\circ} \mathrm{C}$ (Fig. 4). During this period thermoclines developed in the upper $50 \mathrm{~m}$ and salinity dropped from 33.6 to below $33.2 \mathrm{psu}$. The lowest salinities was found in the upper water column at the nearshore stations in May (Tr1 and 3), June (Tr3), and July (Tr1, 4, and 5). On Tr3 in June 1999, relative warm and low saline water was found east and on top of Sukkertop Bank, whereas a core of cold water $\left(<-0.5^{\circ} \mathrm{C}\right)$ was seen west of the bank at depths between 25 and $125 \mathrm{~m}$. In July 2000 , cold water $\left(<0^{\circ} \mathrm{C}\right)$ was distributed at intermediate depths between 50 and $150 \mathrm{~m}$ over the shelf, and salinity showed an increasing trend from south to north ( $\operatorname{Tr} 1$ to 6$)$ (Fig. 4). Density clines $\left(\sigma_{t}\right)$ varied between 25.6 and 28.4 and followed the salinity clines (data not shown). The integrated potential energy $(P)$ showed generally low water stability in the upper $50 \mathrm{~m}\left(P<500 \mathrm{~J} \mathrm{~m}^{-2}\right)$. Exceptions were the offshore stations of $\operatorname{Tr} 3$ in June and the nearshore stations of $\operatorname{Tr} 1,4$, and 5 which were influenced by freshwater runoff from the large West Greenland fjords. There were no significant correlations (or visual relationships) between larval shrimp abundance and mean (5-90 m) temperature or salinity. In May, shrimp larvae were caught in temperatures from -1 to $1.5^{\circ} \mathrm{C}$, and salinities from 33 to 34.2 psu. In June, from -1 to $3.5^{\circ} \mathrm{C}$, and 32.4 to 34 psu. In July, from 0 to $4.5^{\circ} \mathrm{C}$, and 32.4 to $33.8 \mathrm{psu}$.

Copepods dominated the zooplankton. The following species were identified: Calanus finmarchicus, Calanus hyperboreus, Calanus glacialis, Metridia longa, Acartia longiremis, Microcalanus 
TABLE 2a. Mean carapace length $(\mathrm{mm})$ by species, stage, transect, and month.

\begin{tabular}{|c|c|c|c|c|c|c|c|c|c|}
\hline \multirow[b]{2}{*}{ Transect } & \multicolumn{3}{|c|}{ Pandalus sp. Stage ZI } & \multicolumn{3}{|c|}{ P. borealis Stage ZII } & \multicolumn{3}{|c|}{ P. montagui Stage ZII } \\
\hline & No. & Mean & Std. err. & No. & Mean & Std. err. & No. & Mean & Std. err \\
\hline Inshore May 2000 & 511 & 0.92 & 0.01 & 3 & 1.57 & 0.03 & 72 & 0.96 & 0.02 \\
\hline Trl May 2000 & 322 & 1.07 & 0.01 & 11 & 1.67 & 0.10 & 18 & 1.17 & 0.05 \\
\hline Tr3 May 2000 & 397 & 1.12 & 0.01 & 64 & 1.65 & 0.02 & 118 & 1.21 & 0.02 \\
\hline Tr2 June 1999 & - & - & - & 22 & 1.92 & 0.03 & - & - & - \\
\hline Tr3 June 1999 & 14 & 1.11 & 0.03 & 40 & 1.69 & 0.01 & 3 & 1.30 & 0.00 \\
\hline
\end{tabular}

TABLE 2b. Mean carapace length $(\mathrm{mm})$ by species, stage, transect, and month.

\begin{tabular}{|c|c|c|c|c|c|c|c|c|c|c|c|c|}
\hline \multirow[b]{2}{*}{ Transect } & \multicolumn{3}{|c|}{ Stage ZIII } & \multicolumn{3}{|c|}{ Stage ZIV } & \multicolumn{3}{|c|}{ Stage ZV } & \multicolumn{3}{|c|}{ Stage ZVI } \\
\hline & No. & Mean & Std. err. & No. & Mean & Std. err. & No. & Mean & Std. err. & No. & Mean & Std. err. \\
\hline & \multicolumn{12}{|c|}{ P. borealis } \\
\hline Tr3 May 2000 & 1 & 2.00 & - & - & - & - & - & - & - & - & - & - \\
\hline Tr2 June 1999 & 565 & 2.37 & 0.01 & 503 & 3.02 & 0.01 & 4 & 3.15 & 0.10 & - & - & - \\
\hline Tr3 June 1999 & 572 & 2.35 & 0.01 & 985 & 2.95 & 0.01 & 22 & 3.28 & 0.04 & - & - & - \\
\hline Tr1 July 2000 & 34 & 2.34 & 0.04 & 51 & 3.00 & 0.02 & 24 & 3.05 & 0.02 & - & - & - \\
\hline Tr2 July 2000 & 1 & 2.30 & - & 210 & 2.94 & 0.01 & 113 & 3.27 & 0.02 & 12 & 3.78 & 0.05 \\
\hline Tr3 July 2000 & 4 & 2.58 & 0.21 & 53 & 3.03 & 0.02 & 30 & 3.38 & 0.04 & 8 & 3.68 & 0.05 \\
\hline Tr4 July 2000 & 5 & 2.22 & 0.07 & 128 & 2.95 & 0.02 & 35 & 3.25 & 0.04 & 1 & 3.70 & . \\
\hline Tr5 July 2000 & 11 & 2.23 & 0.04 & 193 & 2.98 & 0.01 & 78 & 3.20 & 0.02 & 5 & 3.72 & 0.06 \\
\hline \multirow[t]{2}{*}{ Tr6 July 2000} & 2 & 2.10 & 0 & 47 & 2.99 & 0.03 & 61 & 3.49 & 0.03 & 13 & 3.75 & 0.05 \\
\hline & \multicolumn{12}{|c|}{ P. montagui } \\
\hline Tr3 May 2000 & 4 & 1.75 & 0.09 & - & - & - & - & - & - & - & - & - \\
\hline Tr2 June 1999 & 98 & 1.75 & 0.01 & 289 & 2.28 & 0.01 & 4 & 2.80 & 0.06 & - & - & - \\
\hline Tr3 June 1999 & 20 & 1.79 & 0.02 & 623 & 2.31 & 0.01 & 8 & 2.58 & 0.10 & - & - & - \\
\hline Tr1 July 2000 & 7 & 1.83 & 0.03 & 69 & 2.19 & 0.03 & 26 & 2.29 & 0.08 & 7 & 2.87 & 0.13 \\
\hline Tr2 July 2000 & - & - & - & 58 & 2.47 & 0.02 & 38 & 2.47 & 0.09 & 8 & 2.98 & 0.2 \\
\hline Tr3 July 2000 & - & - & - & 4 & 2.43 & 0.14 & 5 & 2.02 & 0.20 & 7 & 3.09 & 0.09 \\
\hline Tr4 July 2000 & 1 & 1.90 & - & 25 & 2.48 & 0.03 & 28 & 2.64 & 0.05 & 7 & 2.91 & 0.11 \\
\hline Tr5 July 2000 & 4 & 1.83 & 0.07 & 98 & 2.13 & 0.04 & 85 & 2.22 & 0.05 & 6 & 2.53 & 0.36 \\
\hline Tr6 July 2000 & 42 & 1.37 & 0.02 & 84 & 2.04 & 0.03 & 72 & 2.32 & 0.04 & 20 & 3.01 & 0.07 \\
\hline
\end{tabular}

pusillus, Microsetella norvegica, Oithona similis, Oncaea borealis, and Pseudocalanus elongatus. The latter six species were grouped by genus, together with unidentified species of these taxa. A few specimens of Euchaeta norvegica, Temora longicornis, Centropages hamatus, and Pleuromamma robusta were identified; but these were excluded from the distribution maps in Fig. 5.
The larger Calanus copepodites (CI-CVI) showed an increasing abundance from May to July (Fig. 5). C. glacialis and C. hyperboreus dominated in May, whereas $C$. finmarchicus dominated in June and July. Abundance was highest over deep water east and west of the banks in May and July. Abundance was low at the fjord stations sampled in May. The small copepod community consisted predominantly of, Oithona 

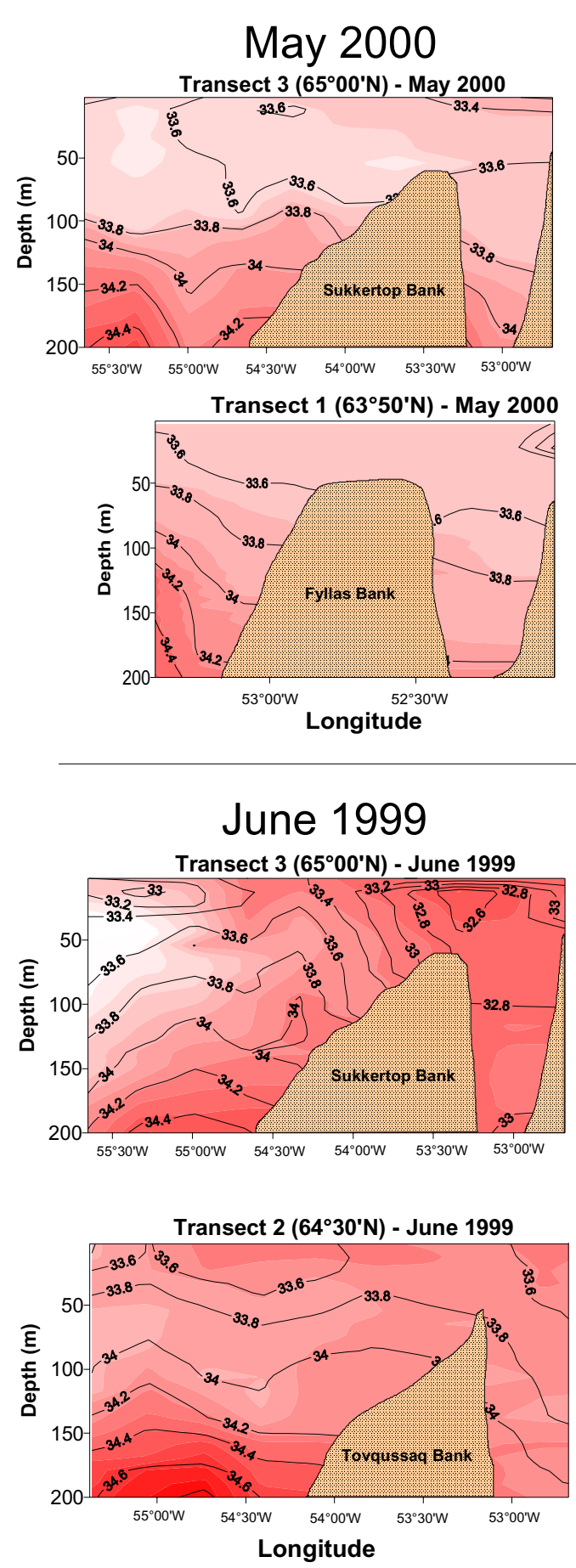
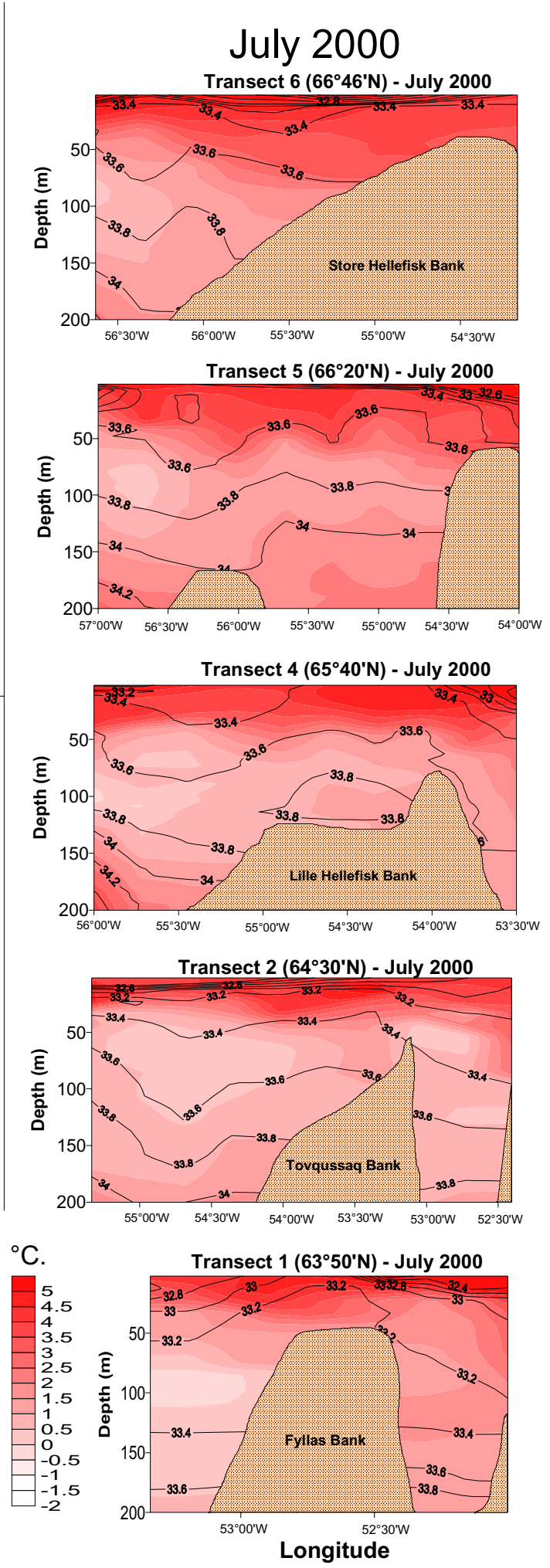

Fig. 4. Vertical sections of temperature $\left({ }^{\circ} \mathrm{C}\right)$, and salinity (psu) along transects 1-6. Temperature is illustrated by different intensity of shading and denoted by inserted bar. 
similes and Microsetella norvegica during all sampling times. Total abundances were at similar low levels in May and June, and highest in July. In May the fjord stations were dominated by Microsetella spp., and Pseudocalanus elongatus. Microcalanus spp. was dominant at one station on $\operatorname{Tr} 3$ in May. Pseudocalanus spp. occurred in high abundance at the two shallow stations nearest to shore of Tr6 in July. The abundance of both large and small copepods was exceptionally high over deep water east and west of the bank on $\operatorname{Tr} 2$ in July (Fig. 5).

In order to relate shrimp larvae distributions and potential food availability, profiles of chlorophyll $a$, biomass of copepods, abundance of copepod egg, nauplii, and invertebrate larvae were compared to the distribution of shrimp larvae biomass along transects (Fig. 6a-c). Chlorophyll $a$ concentrations were highest during the spring bloom in May with peaks (4-6 $\mu \mathrm{g}$ $\left.1^{-1}\right)$ over the shallow parts of Fyllas- and Sukkertop Bank (Fig. 6a-b), with similar high levels at most fjord stations, except at station 5 with much lower chlorophyll $a$ values $\left(<0.7 \mu \mathrm{g} \mathrm{l}^{-1}\right)$. In June, a postbloom situation prevailed resulting in low autotrophic biomass and low chlorophyll $a$ values over Sukkertop Bank, but peak chlorophyll $a$ values $\left(1 \mu \mathrm{g} \mathrm{l}^{-1}\right)$ in the upper water column were seen at the westernmost stations of $\operatorname{Tr} 3$ (Fig. 6b). In July, subsurface blooms with chlorophyll $a$ peaks $\left(1-2 \mu \mathrm{g} 1^{-1}\right)$ at water depths of about $30 \mathrm{~m}$ were seen along $\operatorname{Tr} 1,4$, and 5 (Fig. 6a and $6 \mathrm{c})$.

The large Calanus spp. copepodites by far dominated the plankton community structure, with Pseudocalanus spp., Metridia longa, and Oithona spp. comprising most of the remaining copepod biomass (Fig. 6a-d). Visual inspections of Figs. 6a-d indicated generally higher biomasses of copepods, and higher abundance of copepod egg, nauplii, and invertebrate larvae at stations with higher concentrations of chlorophyll $a$. Exceptions were on top of Fyllas and Sukkertop Bank in May with high chlorophyll $a$ concentrations but low copepod biomass and at the inshore stations with very low biomass of Calanus. Shrimp larval biomass was generally insignificant compared to the copepod biomass. However, at one station at $\operatorname{Tr} 1$ (May) and on most fjord stations the shrimp larvae biomass was relatively high compared to the copepod biomass. The exception was station 5 (Fig. 6d) with low chlorophyll $a$ values. The shrimp larvae abundance seemed to be related to areas of high chlorophyll $a$ concentrations at the fjord stations in May and on $\operatorname{Tr} 1$ in July, however there were no such relationships on other transects in June and July. There were no correlations ( $p>0.05$ ) or visual patterns between abundances of larval shrimp and individual zooplankton species, species groups (individual or combined) or size classes (50-100, 1001000 , and $\geq 1000 \mu \mathrm{m}$ ) at any time (Fig. 6a-d). Shrimp larvae were abundant over deep water in the channels east of banks and over the banks.

\section{Current tracking}

The two SVP buoys deployed east and west of Fyllas Bank on May 12 and 13 both showed a net northward drift (Fig. 7). The trajectories of the drifters intersected several times and showed meandering paths. Occasionally eddies and gyres trapped the buoys for periods of 2-3 weeks. Overall drift distances and mean velocities differed between the two buoys (Fig. 7 , Table 3). Based on data from both buoys the overall mean net northbound current was estimated to about $3.1 \mathrm{~km} \mathrm{~d}^{-1}$ for the period from deployment (12-13 May) to 31 July.

During most of May 2000, winds blowing from a northerly direction and in periods after deployment relatively strong northerly wind $\left(8-15 \mathrm{~m} \mathrm{~s}^{-1}\right)$ prevailed (Fig. 8). Although northerly winds, the two buoys drifted northward into the Sukkertop Deep at a mean speed of $10-12 \mathrm{~km} \mathrm{~d}^{-1}$ until they were trapped in eddies on 22 May. After 23 May both buoys drifted west and buoy No.3378 became trapped in a new eddy, while bouy No. 3377 followed a cyclonic circulation before being trapped in an eddy at the southern edge of Tovqussaq Bank (Fig. 7).

In June and July 2000, wind speeds were generally below $5 \mathrm{~m} \mathrm{~s}^{-1}$ and seldom exceeded $10 \mathrm{~m} \mathrm{~s}^{-1}$ (Fig. 8). However, from 25 July to 8 August strong winds (15$28 \mathrm{~m} \mathrm{~s}^{-1}$ ) from the south dominated the wind field. For a period of July the drift patterns of the buoys showed daily tidal induced anticyclonic circulation of about $5 \mathrm{~km}$ in diameter, with drift speeds often exceeding $1.8 \mathrm{~km} \mathrm{~h}^{-1}\left(0.5 \mathrm{~m} \mathrm{~s}^{-1}\right)$ (Fig. 7). At about $67^{\circ} \mathrm{N}$, buoy No. 3378 maintained circulation around the shallow Store Hellefisk Bank $(<30 \mathrm{~m})$ for seven weeks from 31 July to 19 September. Thereafter it drifted north along the same route as buoy No. 3377 until it came aground on coast south of Disko Bay on 17 November. Buoy No. 3377 maintained anticyclonic circulation over Disko Bank from mid September to mid October before drifting north and before it was forced south by the developing winter "West ice" in mid December (Fig. 7). 

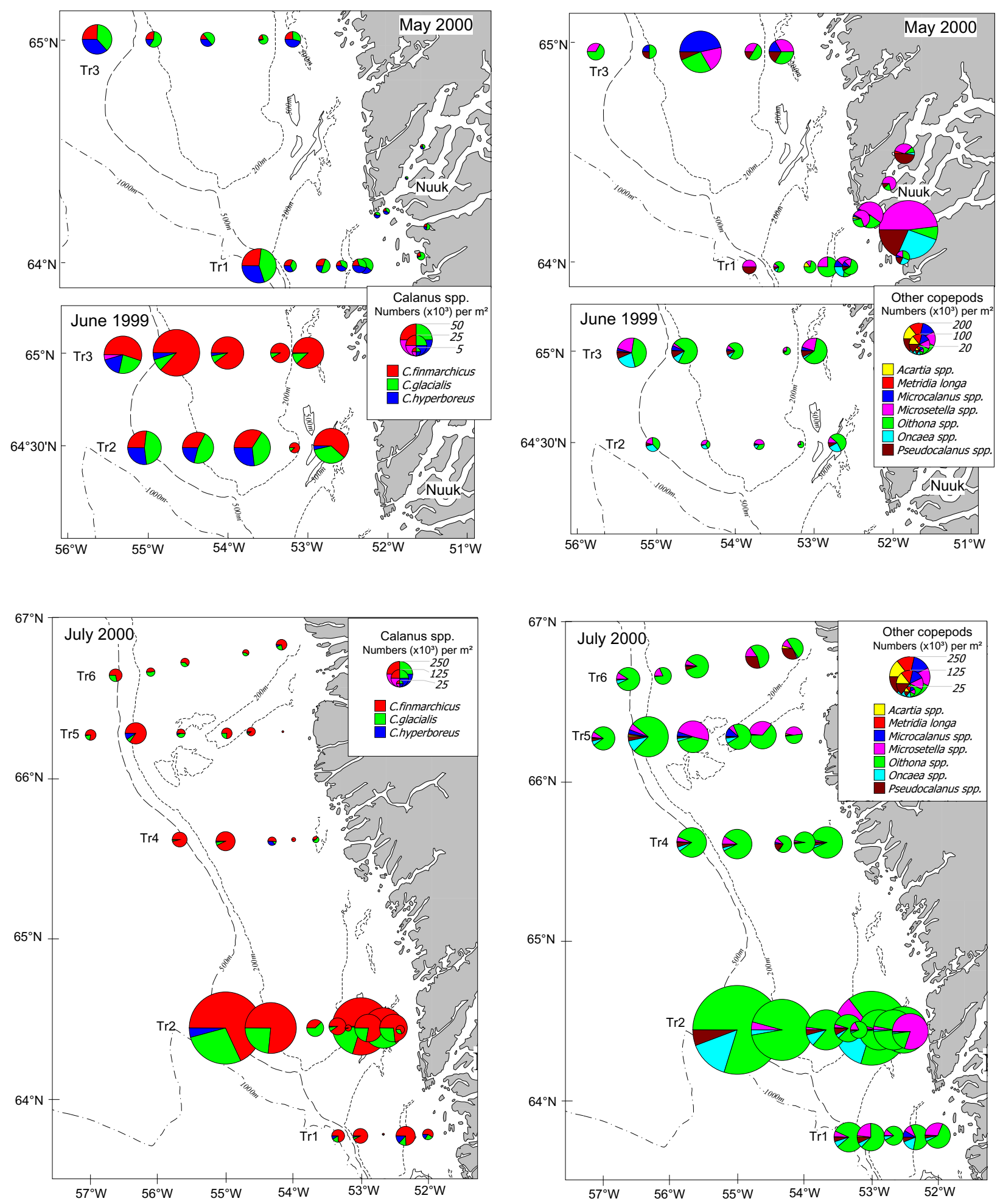

Fig. 5. Distribution, and abundance of Calanus spp. (left panels) and other copepods (right panels) in May 2000, June 1999, and July 2000. Dot sizes are graduated by square root. Note different scales between left and right panel. 

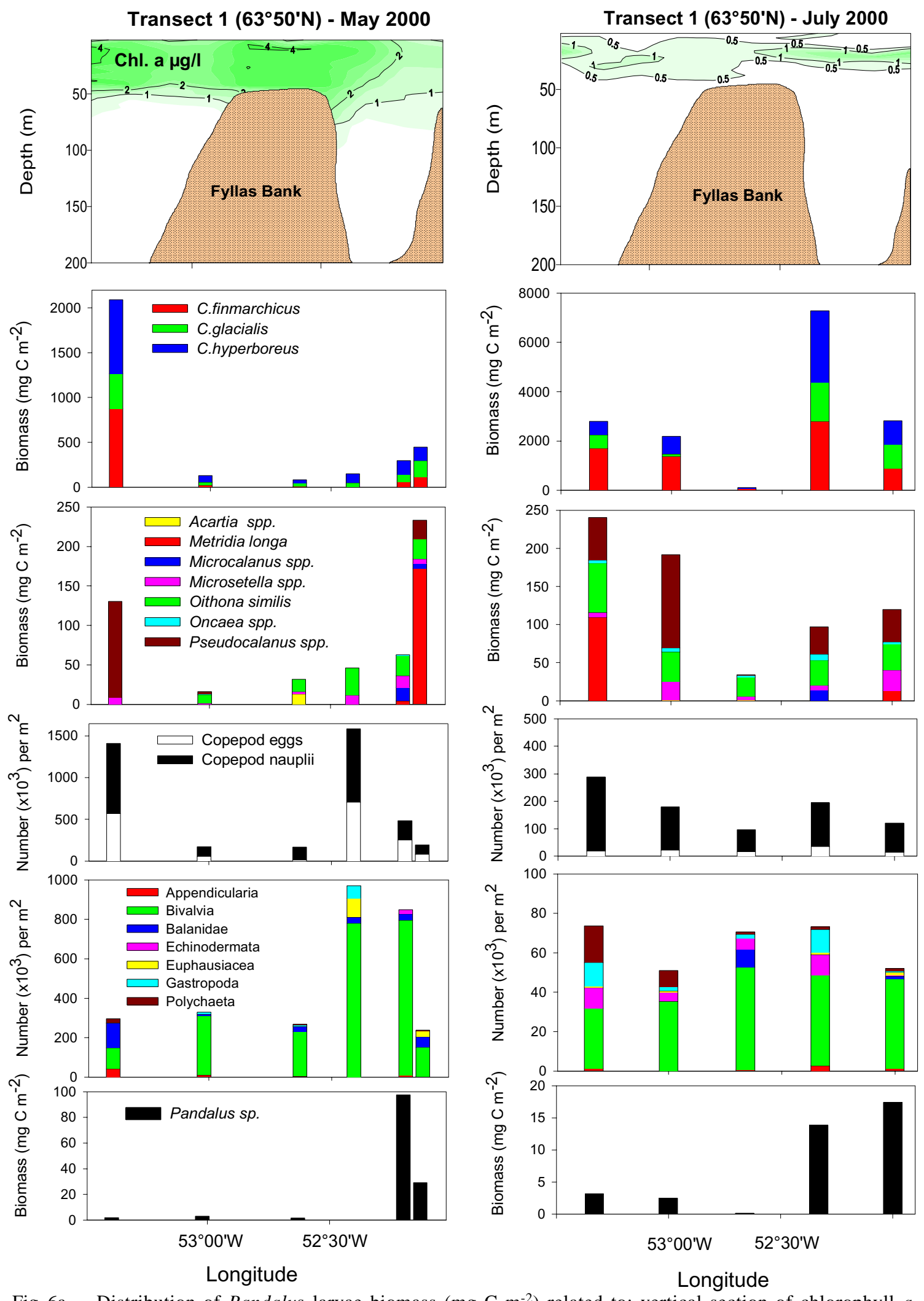

Fig. 6a. Distribution of Pandalus larvae biomass $\left(\mathrm{mg} \mathrm{C} \mathrm{m}^{-2}\right)$ related to: vertical section of chlorophyll $a$ concentration in $\mu \mathrm{g}^{-1}$, composition of Calanus spp. and other copepod biomass $\left(\mathrm{mg} \mathrm{C} \mathrm{m}^{-2}\right)$, number of copepod eggs, nauplii, and other invertebrate larvae $\left(\times 10^{3} \mathrm{~m}^{-2}\right)$ along transect 1 in May 2000 (left panels), and July 2000 (right panels). 

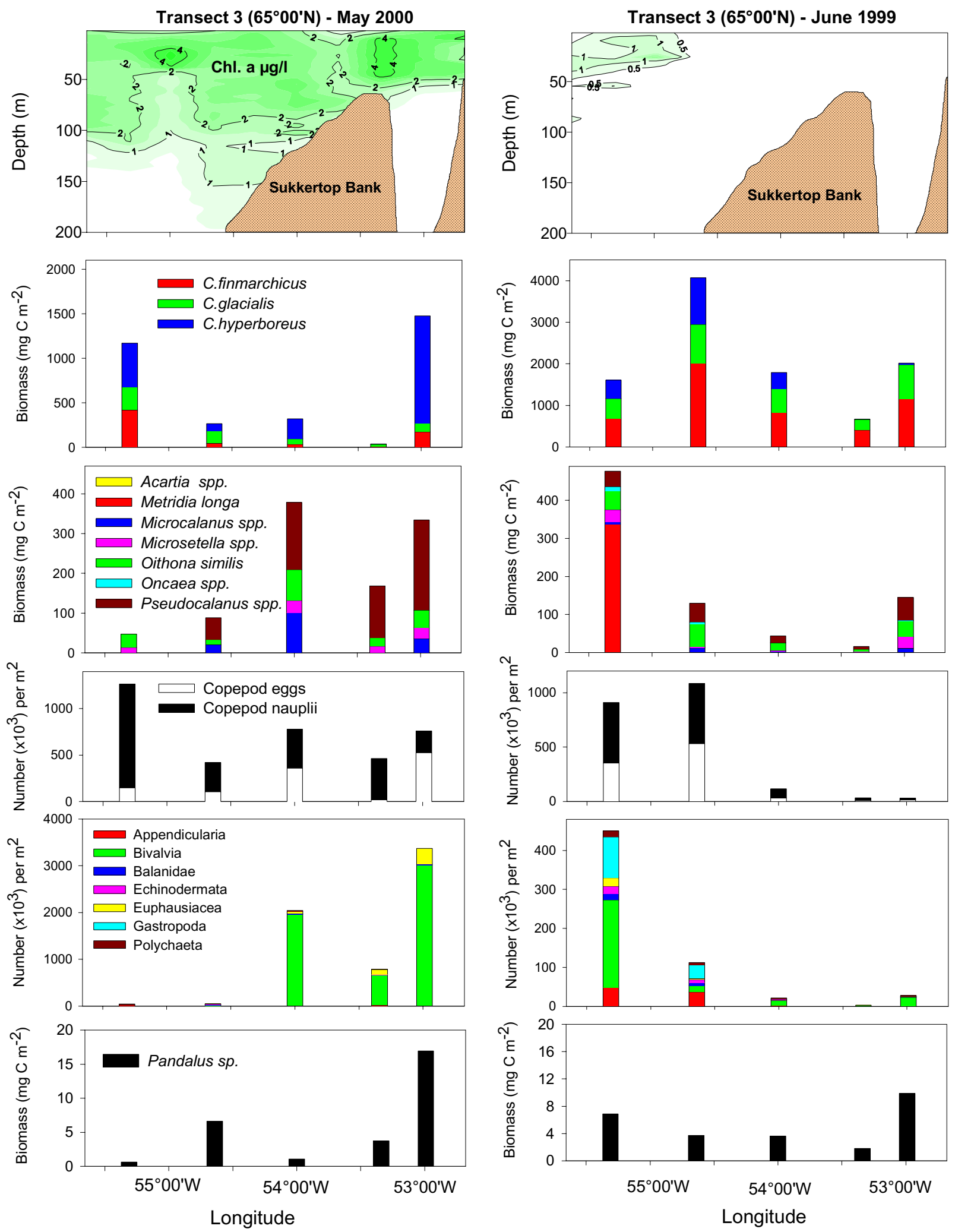

Fig. 6b. Distribution of Pandalus larvae biomass $\left(\mathrm{mg} \mathrm{C} \mathrm{m}^{-2}\right)$ related to: vertical section of chlorophyll $a$ concentration in

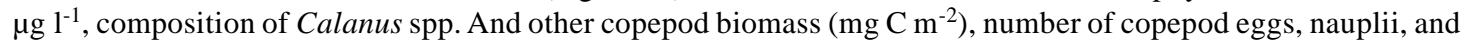
other invertebrate larvae $\left(\times 10^{3} \mathrm{~m}^{-2}\right)$ along transect 3 in May 2000 (left panels), and June 1999 (right panels). 

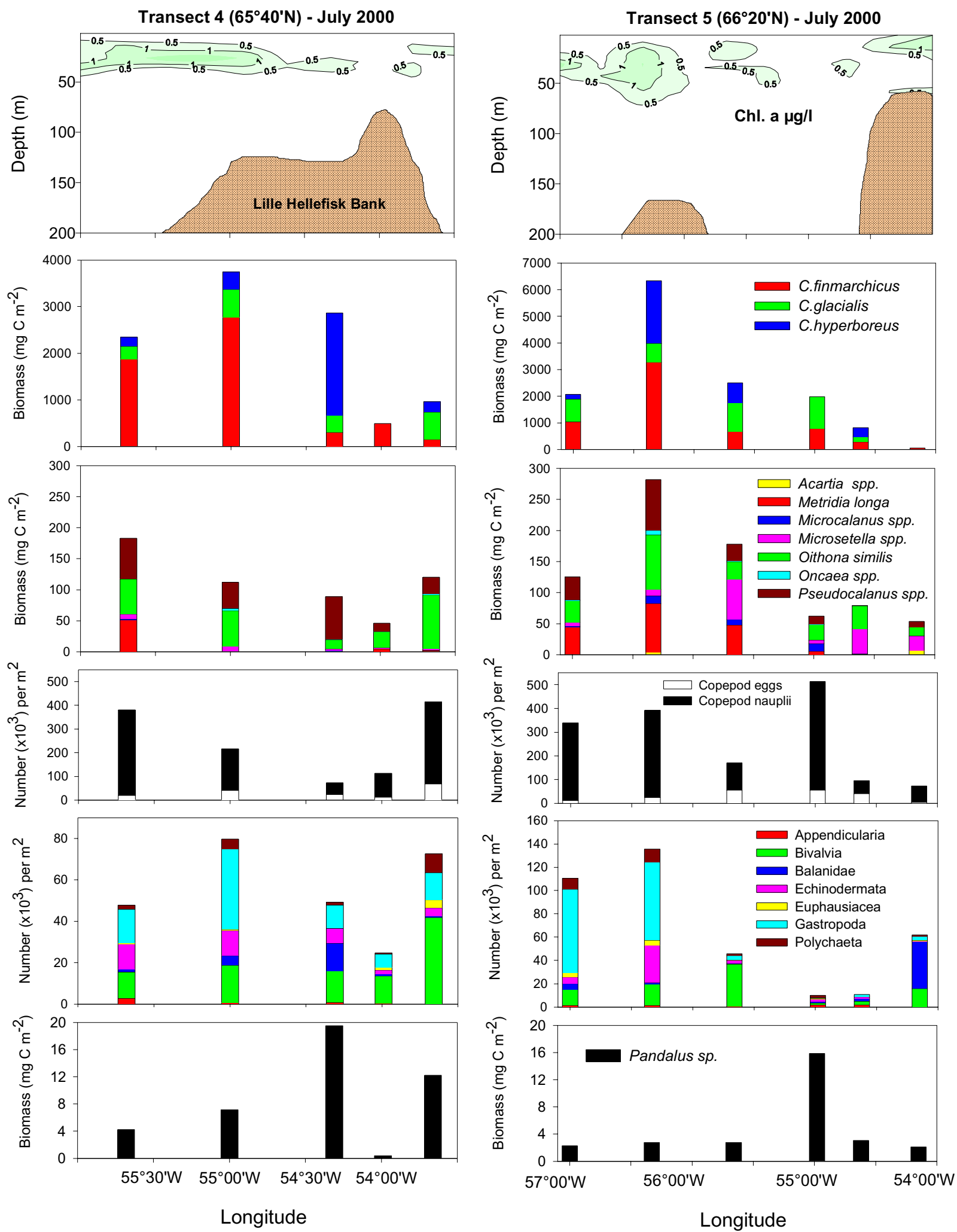

Fig. 6c. Distribution of Pandalus larvae biomass ( $\mathrm{mg} \mathrm{C} \mathrm{m}^{-2}$ ) related to: vertical section of chlorophyll $a$ density in $\mu \mathrm{g} \mathrm{l}^{-1}$, composition of Calanus spp. and other copepod biomass ( $\mathrm{mg} \mathrm{C} \mathrm{m}^{-2}$ ), number of copepod eggs, nauplii, and other invertebrate larvae $\left(\times 10^{3} \mathrm{~m}^{-2}\right)$ along transect 4 in July 2000 (left panels), and transect $5 \mathrm{July} 2000$ (right panels). 

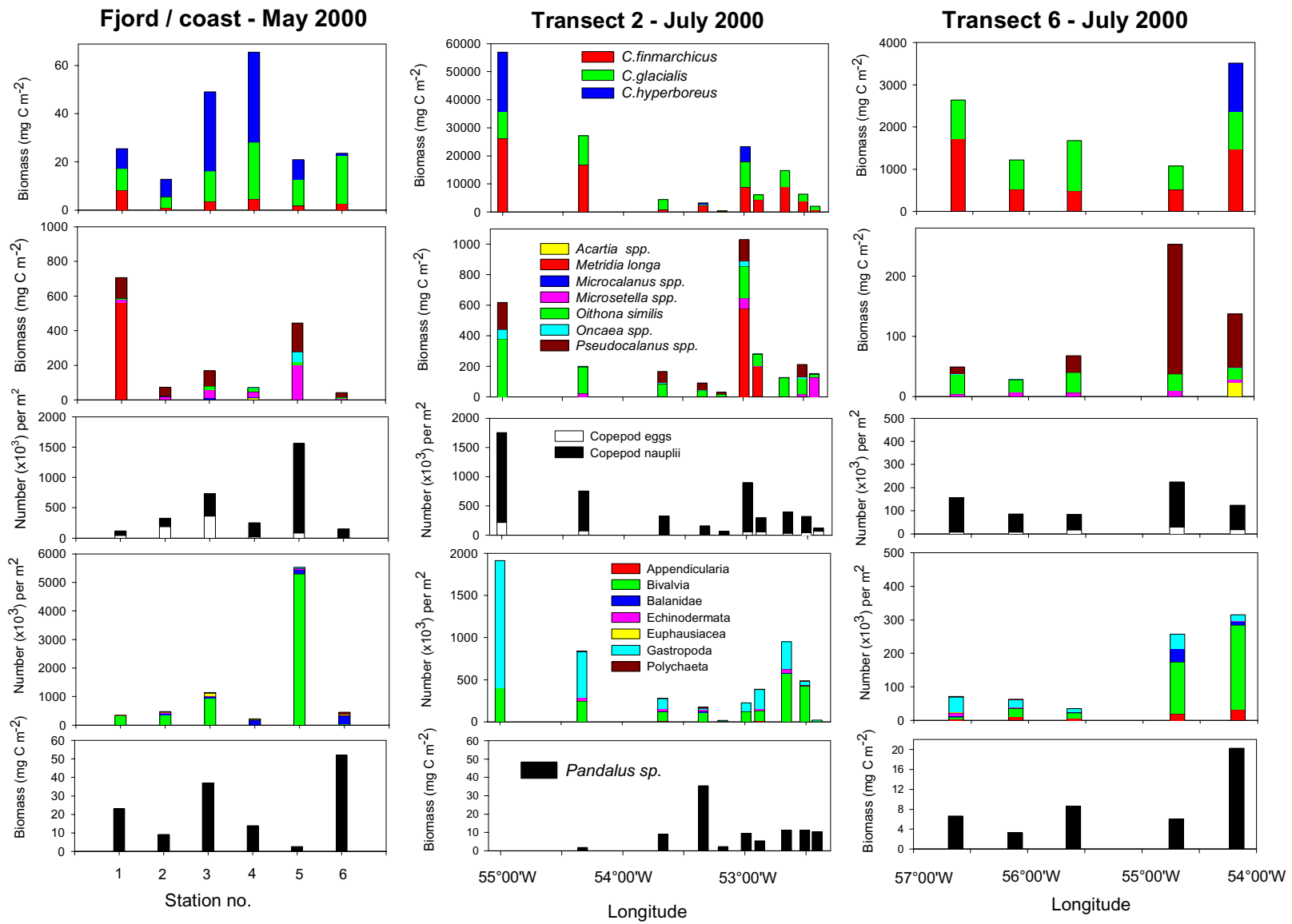

Fig. 6d. Distribution of Pandalus larvae biomass $\left(\mathrm{mg} \mathrm{C} \mathrm{m}^{-2}\right)$ related to: composition of Calanus spp. and other copepod biomass $\left(\mathrm{mg} \mathrm{C} \mathrm{m}^{-2}\right)$, number of copepod eggs, nauplii, and other invertebrate larvae $\left(\times 10^{3} \mathrm{~m}^{-2}\right)$ on six inshore stations in May 2000 (left panels), along transect 2 in July 2000 (mid panels), and transect 6 July 2000 (right panels).

\section{Discussion}

\section{Larval Pandalus distribution, abundance, and stage development}

We found six pelagic development stages in two species of Pandalus larvae. The larger $P$. borealis larvae were slightly less developed than $P$. montagui, suggesting later hatching or slower development time of $P$. borealis larvae. The larval distribution, abundance, and proportion of ZIII and ZIV along Tr3 in June 1999 were similar to findings in early July 1996 (Pedersen, 1998).

In West Greenland P. borealis spawns (extrudes eggs) in offshore waters beginning in July and ending in late August or early September (Horsted, 1978). The egg mass is carried by females until spring (March-April) when they move to shallow water to release the first pelagic larval stage (Shumway et al., 1985). The exact time of hatching is directly related to water temperature, warmer water resulting in earlier hatching and a shorter pelagic larval phase (Shumway et al., 1985). The planktonic larvae are thought to drift more or less passively during five zoeal stages and settle to the bottom during the sixth (megalopa) stage (Berkeley, 1930; Horsted et al., MS 1978; Shumway et al., 1985). According to Horsted and Smidt (1956) planktonic larval influx into Disko Bay and many fjords in West Greenland may be critical to recruitment of $P$. borealis in those areas. During the May 2000 cruise, Pandalus larvae concentrated east of Fyllas Bank near the coast, and at fjord stations in the Nuuk area. Most larvae were ZI and probably newly hatched. Previous plankton studies from West Greenland did not catch Pandalid larvae earlier than May (Horsted and Smidt, 1956; Smidt, 1979), therefore hatching probably occurred in late April and early 

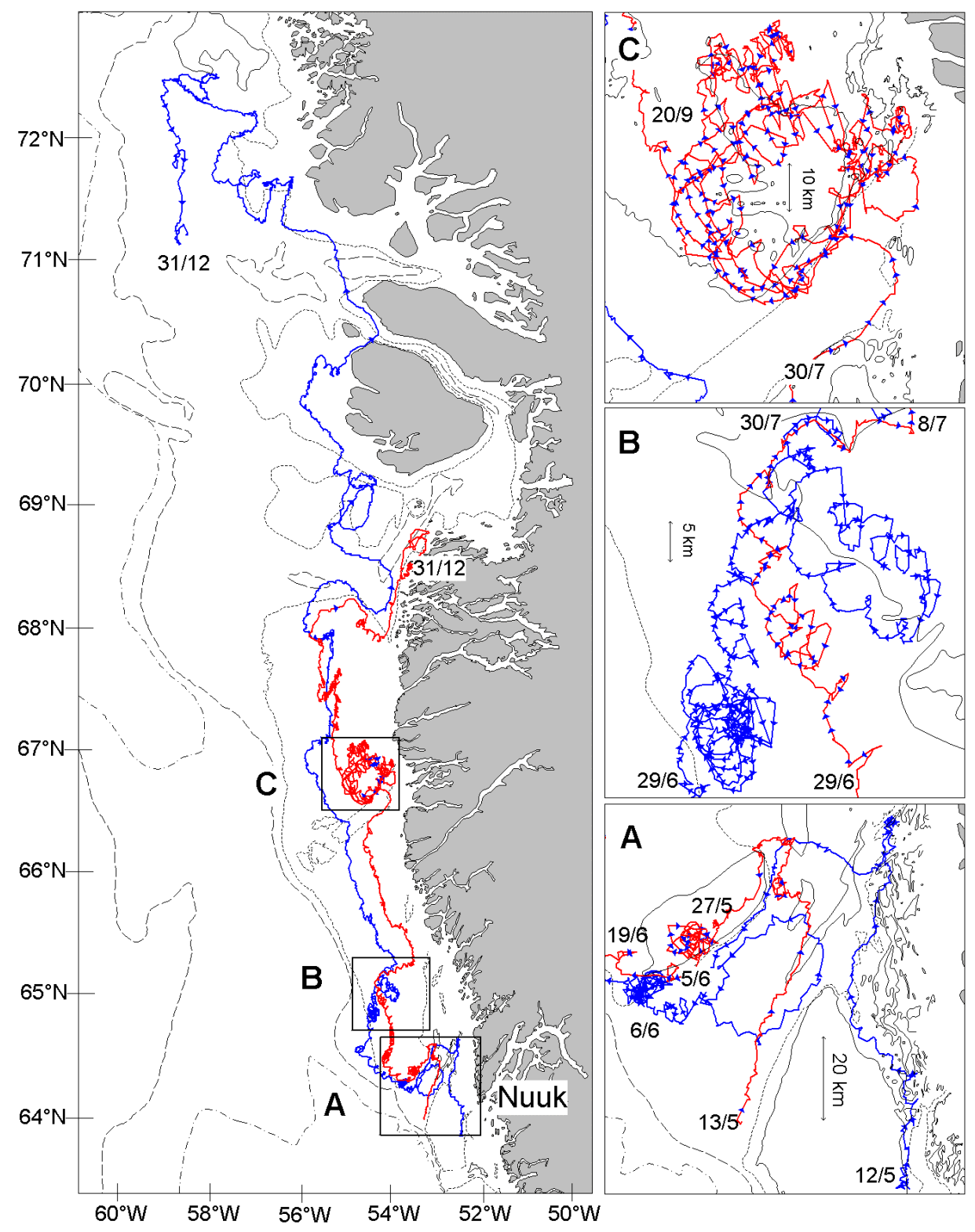

Fig. 7. Drift of the two satellite tracked SVP buoys (drogue at $30 \mathrm{~m}$ ), No. 3377 (blue line), 12/5-31/12, 2000 and No. 3378 (red line), 13/5-31/12, 2000. A: following the bottom topography (No. 3377: 12/5-19/6; No. 3378: 13/5-6/6). B: daily tidal induced clockwise circulation of about $5 \mathrm{~km}$ in diameter (No. 3377: 29/6-30/7; No. 3378: 29/6-8/7). C: anticyclonic circulation around bank (No. 3378: 30/7-20/9).

May. Progressively later stage larvae were caught during June 1999 and July 2000. Although ZIV dominated, ZV and ZVI larvae were also present in July. This indicated a somewhat slower stage development and longer duration of the planktonic larval phase in waters of West Greenland compared to $P$. borealis populations in the Barents Sea and around Iceland. In the former ZVI larvae were present already in late-June and early July (Lysy, 1983), while at the same time period ZIV or early ZV larvae were present in waters northwest of Iceland (Astthorsson and Gislason, 1991). We estimate the planktonic phase 
TABLE 3. Northern drift distances of the two satellite tracked SVP drifting buoys (drouge at $30 \mathrm{~m}$ ), 12-13 May-31 July 2000.

\begin{tabular}{|c|c|c|c|c|c|c|c|c|}
\hline \multirow[b]{2}{*}{ Buoy } & \multicolumn{2}{|c|}{ 12/13 - 31 May } & \multicolumn{2}{|c|}{1 - 30 June } & \multicolumn{2}{|c|}{$1-31$ July } & \multicolumn{2}{|c|}{ 12/13 May - 31 July } \\
\hline & $\begin{array}{r}\text { Distance } \\
(\mathrm{km})\end{array}$ & $\begin{array}{r}\text { Mean velocity } \\
(\mathrm{km} / \text { day })\end{array}$ & $\begin{array}{r}\text { Distance } \\
(\mathrm{km})\end{array}$ & $\begin{array}{r}\text { Mean velocity } \\
(\mathrm{km} / \text { day })\end{array}$ & $\begin{array}{r}\text { Distance } \\
(\mathrm{km})\end{array}$ & $\begin{array}{r}\text { Mean velocity } \\
(\mathrm{km} / \text { day })\end{array}$ & $\begin{array}{r}\text { Distance } \\
(\mathrm{km})\end{array}$ & $\begin{array}{r}\text { Mean velocity } \\
(\mathrm{km} / \text { day })\end{array}$ \\
\hline ID no. 3377 & 50 & 2.6 & 80 & 2.6 & 50 & 1.6 & 181 & 2.3 \\
\hline ID no. 3378 & 45 & 2.4 & 64 & 2.1 & 200 & 6.5 & 311 & 3.9 \\
\hline Mean & 47.5 & 2.5 & 72 & 2.4 & 125 & 4.1 & 246 & 3.1 \\
\hline
\end{tabular}

of $P$. borealis in West Greenland to be $\sim 4$ months which is similar to larval development in West Murman coastal waters (Lysy, MS 1981). Differences in sea-temperature are likely to be responsible for the slower development time. Temperature and so called "thermal increase enhancement" have a direct effect on $P$. borealis larvae by increasing growth and reducing mortality and development time (Shumway et al., 1985; Rasmussen, MS 1993; Tande et al., 1994; Rasmussen and Tande, 1995). However, periods of starvation or restricted food availability may prolong stage duration and increase mortality (T. Rasmussen, pers. comm.).

The depth-integrated plankton hauls presented in this study provided no information on vertical distribution of different stages, migrations, or time and stage of settling. Ouellet and Lefaivre (1994) found that ZI and ZII $P$. borealis larvae concentrated in the upper layers $(<30 \mathrm{~m})$ above the permanent pycnocline and coincident with subsurface chlorophyll $a$ and suspended particle concentration maxima. During the cruise in May, plankton pump samples at different depths showed deeper and wider vertical distributions of ZI and ZII larvae (S. A. Pedersen, unpublished data). According to Rasmussen et al. (MS 2000), newly hatched $P$. borealis are positively phototactic, while ZIII the larvae tend to actively seek deeper water. The ZV is considered to be semi benthic (Rasmussen et al., MS 2000). In a study of temperature and salinity preference, Rasmussen et al. (MS 2000) found that all stages of larval $P$. borealis seek the highest available temperature $\left(4.6^{\circ} \mathrm{C}\right)$. ZI and ZII larvae preferred a salinity of $28 \mathrm{psu}$, whereas ZIII and ZIV preferred higher salinities. Activity was reduced when exposed to low temperatures $\left(0^{\circ} \mathrm{C}\right)$, but no mortality was observed (Rasmussen et al., MS 2000). The pelagic occurrence of ZV and ZVI in our studies may be due to avoidance of the cold intermediate water at depths of about $50 \mathrm{~m}$, buoyancy effects of hydrographic features or vertical migration in search for food. Vertical distribution and planktonic occurrence of $\mathrm{ZV}$ and ZVI larvae may vary between areas and times due to differences in hydrographic features, food availability and biochemical larval condition.

The larval distribution patterns and lack of clear differences in the proportion of stages across banks and between transects, indicates wide larval dispersal and a relatively short period of hatching. According to Anderson (2000) larval emergence and recruitment success in $P$. borealis seems to be timed to and favoured by relatively late zooplankton peak abundance observed during a cold ecosystem regime.

\section{Hydrography and biological habitat characteristics}

The upper $200 \mathrm{~m}$ during May, June, and July were dominated by Polar water, which is characterised by temperatures below $0^{\circ} \mathrm{C}$ (increasing to $3-5^{\circ} \mathrm{C}$ in the surface layer during summer) and salinities below 34.4 psu (Buch, 2000). A hydrographic frontal zone between cold Polar water and warmer mixed shelf water over the bank was most clearly seen in June on the western part of Tr3 (Fig. 4). In May and July, fronts were difficult to identify across transects. Vertical clines were clearly seen between warmer and less saline water in the surface layers and near the coast due to freshwater runoff. The coarse spatial and temporal resolution of hydrographical data measurements makes detection of frontal processes difficult. Fronts may only occur periodically within the sampled areas. We found no relationship between larval shrimp abundance and water mass characteristics. This is similar to findings in Gulf of St. Lawrence and West Greenland (Ouellet et al., 1990; Pedersen and Rice, 2002). 

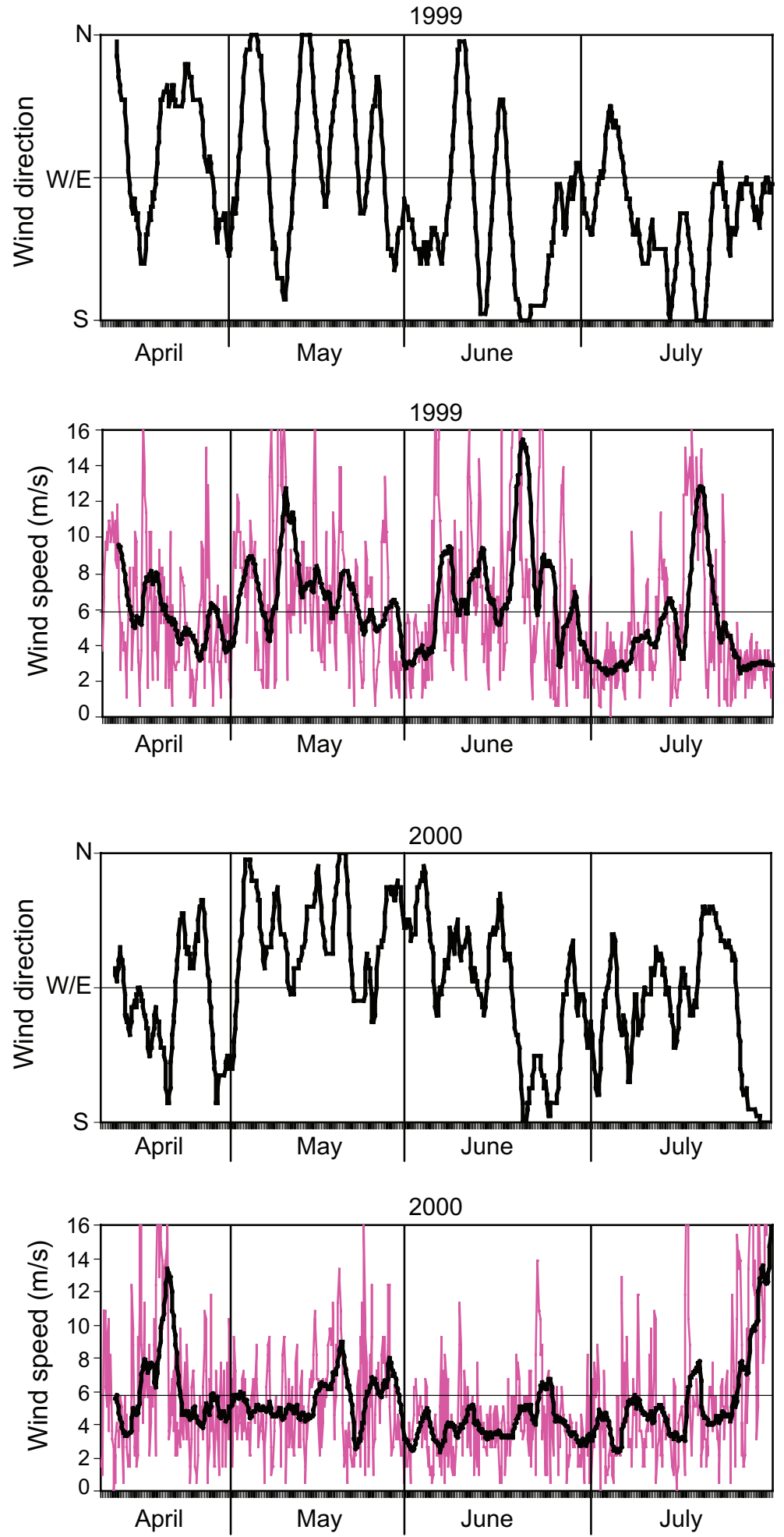

Fig. 8. Temporal variation in wind direction and speed in 1999 and 2000. Solid line is moving average. Data: from the Nuuk meteorological station, West Greenland. 
In May and June, chlorophyll $a$ was concentrated in the relatively cold Polar water mass (Fig. 6a,b). During the spring bloom in May the phytoplankton biomass $\left(92 \pm 45 \mathrm{mg} \mathrm{C} \mathrm{m}^{-3}\right.$ ) was dominated by diatoms of Thalassiosira spp. and Chaetoceros spp. (Poulsen and Reuss, 2002). Fjord station 4 (Fig. 1) deviated from the spring-bloom stations with lower phytoplankton standing stock ( $30 \mathrm{mg} \mathrm{C} \mathrm{m}^{-3}$ ). In June, a post-bloom situation prevailed on most of $\operatorname{Tr} 3$ resulting in a very low phytoplankton biomass $(2 \pm 1$

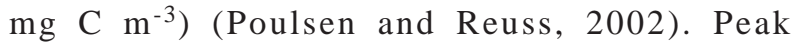
phytoplankton biomasses $\left(30 \mathrm{mg} \mathrm{C} \mathrm{m}^{-3}\right.$ ) were found at the western part of $\operatorname{Tr} 3$ where diatoms of Chaetoceros spp. dominated. In July pronounced subsurface concentrations of chlorophyll $a$ were observed in the upper $50 \mathrm{~m}$ of the water column on $\operatorname{Tr} 1, \operatorname{Tr} 4$, and $\operatorname{Tr} 5$ (Fig. 6a,c). The phytoplankton composition of these subsurface blooms was not investigated, but diatoms probably dominated (Nielsen and Hansen, 1999).

The mesozooplankton community over the West Greenland shelf in May, June, and July was dominated by copepods. The three species of large copepods Calanus finmarchicus, C. glacialis, and C. hyperboreus were dominating in terms of biomass. In terms of number the smaller copepods, Oithona spp. and Microsetella spp., dominated. Other studies have described the distribution and dominance of Calanus spp. in West Greenland plankton communities (MacLellan, 1967; Nielsen and Hansen, 1995; Pedersen et al., 1999; Hansen et al., 1999; Pedersen and Smidt, 2000; Madsen et al., 2001). The biomasses of large and small copepods in the present study were in the same range as found in other studies conducted in the same areas in July (Pedersen et al., 1999). An exception was the unusual high abundance and biomass of copepods and invertebrates at stations over deep water on $\operatorname{Tr} 2$ in July 2000 (Fig. 6d), which was an order of magnitude higher than other transects. The area crossed by $\operatorname{Tr} 2$ is an important summer feeding area for baleen whales, mainly humpback whale (Megaptera novaeangliae), which supports the findings of exceptional high plankton densities here (Finn Larsen, DIFRES, Charlottenlund, Denmark, pers. comm.). Special hydrographical features in this area may cause plankton aggregations. As the northward drifting West Greenland Current meets Sukkertop Deep and pass west of Tovqussaq- and Sukkertop Bank it produces complex gyres and circulation patterns in Sukkertop Deep and along the bank slopes which may aggregate zooplankton (Fig. 7).
We did not find relationships between larval shrimp abundance and either chlorophyll $a$ concentrations or zooplankton abundance (species, groups or sizes classes). According to Stickney and Perkins (1981) the food of larval P. borealis is predominately diatoms taken through chance encounter, but also zooplankton is eaten when it is abundant. It may become more important than phytoplankton as the larvae grow during spring (Stickney and Perkins, 1981). Their laboratory observations showed that larvae could capture particles from $100 \mu \mathrm{m}$ to $1 \mathrm{~mm}$ efficiently, with efficiency dropping off above and below these limits, and cannibalism was not uncommon. Rasmussen et al. (MS 2000) investigated food preferences of shrimp larvae in laboratory experiments and they found ZI and ZII had higher clearance rates for alge than for other food items offered, while ZIII lost interest in planktonic algae. Shrimp larvae in ZIII to ZVI actively chased and ate smaller capelin and cod larvae when these were introduced (Rasmussen et al., MS 2000).

During laboratory studies of food concentration and shrimp larval survival, Stickney and Perkins (1981) found the following concentrations necessary for high survival: $400-1000$ diatoms $1^{-1}$ (at $4^{\circ} \mathrm{C}$ ), 1000 copepod nauplii $\mathrm{l}^{-1}$ or 500 copepodites $\mathrm{l}^{-1}$ (at $6^{\circ} \mathrm{C}$ ). They also found that the concentrations of phyto- and zooplankton required for survival in laboratory experiments was far greater than would normally be found in the wild. Concentrations of the dominant diatoms were in the range 450-1220 cells $1^{-1}$ along $\operatorname{Tr} 1$ and $\operatorname{Tr} 3$ in May (Poulsen and Reuss, 2002). We calculated the average (depth-integrated) concentrations of potential shrimp larvae food to be in the range of 1-100 zooplankton particles $1^{-1}$ in June 1999 and July 2000. Actual food concentrations are likely to be higher because the particles are probably not evenly distributed in the water column. However, Pedersen and Storm (2002) found that most larvae in July exhibited low lipid condition, indicating generally low food availability. Temperatures were lower in the present study than during the observations by Stickney and Perkins (1981). The food particle concentrations, either phyto- or zooplankton, necessary to meet the requirements of shrimp larvae will depend on many factors e.g. larval shrimp size, temperature, the food value of the particle (species, size, energy content, etc.), predator and prey movements/activity, turbulence, and encounter rates (Savenkoff et al., MS 1995; Rasmussen et al., MS 2000; MacKenzie, 2000; Incze et al., 2001; Werner et al., 2001). Werner et al. (2001) have investigated coupled models to explore 
the relative importance of biological and physical variables on the growth and survival of larval cod and haddock on Georges Bank. These model studies are relevant for studies of shrimp and fish recruitment in West Greenland waters. Although, modelling of shrimp recruitment differs by e.g. the omnivorous nature of the larvae and the presumably less important size specific predator-prey interactions. According to MacKenzie (2000), an important question to answer for future studies of fish stock recruitment is: Are the surviving individuals of a larval fish (or shrimp) cohort a subset of offspring which have experienced some optimal level of turbulence that enabled high growth or survival rates?

\section{Larval drift}

Hydrographic features, fronts and eddies may function as barriers to larval shrimp transport, or contribute to larval retention (Ivanov, 1967; Horsted et al., MS 1978; Iles and Sinclair, 1982; Sinclair, 1988). In West Greenland larval drift by surface currents is assumed to be essential for the recruitment to downstream fishing areas and fjords, whereas larval retention may dominate in other areas. According to Horsted et al. (MS 1978) it is likely that current gyres occur in the shrimp area northwest of Store Hellefisk Bank and that the stock in this area is recruited mainly by local spawning. However, recruitment to some of the fishing grounds in Disko Bay appears to be dependant on drift from offshore shrimp populations. Larvae hatched in the bay itself may contribute to the local stock but some may also drift (through the Vaigat northeast of Disko) to more northerly offshore shrimp distribution areas. Knowledge of larval drift paths and hence links between subpopulations is important to develop management strategies, which take spatial variation of the recruitment process into account.

SVP drift buoy data indicated a net northward drift of about $3.1 \mathrm{~km} \mathrm{~d}^{-1}$ for the period from deployment (12-13 May) to 31 July. If we assume a shrimp cohort drifts in a similar fashion we can expect a net northward larval transport of 200-400 km during the pelagic larval life of $\sim 4$ months. This drift distance is somewhat less than previously assumed by Horsted et al. (MS 1978) due to the many gyres and circulations entrapping the buoys in this study. Wind fields and tidal motions are important in the generation of water mass transport e.g. up- and downwelling, tidal-front entrainment, advection and retention of plankton over the West Greenland shelf as elsewhere (Cushing, 1990; Lochmann et al., 1997; Blanton et al., 1999; Incze and Naimie, 2000; Lough and Manning, 2001). Observations on the Scotian Shelf indicated that physically driven retention, not differential mortality, was responsible for high abundances of cod larvae at a convergent front (Lochmann et al., 1997). After deployment in May the buoys drifted north- and coastward. Northerly winds prevailed during this period and offshore Ekman drift in the upper layer replaced by upwardmoving water from below may have forced the buoys (and newly hatched larval shrimp) north- and coastward. During June and July the buoys may have followed currents along wind and tidally induced gyres and hydrographic fronts. However, better spatial and temporal coverage will be required to confirm this and its biological implications.

\section{Recruitment and year-class strength}

The distribution of juvenile shrimp during the annual shrimp survey in 2000 and 2001 showed highest abundances in the deeps between the banks of southwest Greenland between $62^{\circ} \mathrm{N}$ and $65^{\circ} \mathrm{N}$, north of Store Hellefisk Bank and in Disko Bay (Fig. 9; Kanneworff and Wieland, MS 2001; Wieland and Carlsson, MS 2001). Lilly et al. (1998) reported a wide spatial distribution of age- 0 P. borealis whereas older juveniles were found primarily in shallow water and with increasing size, shrimp moved into deeper water $(300-500 \mathrm{~m})$. In West Greenland, analyses indicated that small males occur first in several relative small and isolated areas and extend over a wider region with increasing size and age (Wieland and Carlsson, MS 2001). During the 1990s the offshore West Greenland shrimp fishery moved southward, which may indicate stock migrations towards preferable habitat temperatures due to the changes in the ocean climate (Hvingel, MS 2001; Buch et al., 2002). High fishing pressure on the shrimp population at Southwest Greenland may reduce future recruitment in this region but also in the areas further north.

In the Barents Sea, M. Aschan, Norwegian Institute of Fisheries and Aquaculture, Troms $\varnothing$, Norway, pers. comm., found strong correlations between total egg production, number of spawning females, and recruitment index for age- 1 shrimps. According to M. Aschan (pers. comm.), this indicates that natural mortality of shrimp larvae in the Barents Sea is constant the first year. Also in the Barent Sea, Pedersen et al. (2002) found larval shrimp transport patterns to vary between years, with the effect of annually different dispersion pattern of larval shrimp settlements. According to Pedersen et al. (2002) the 

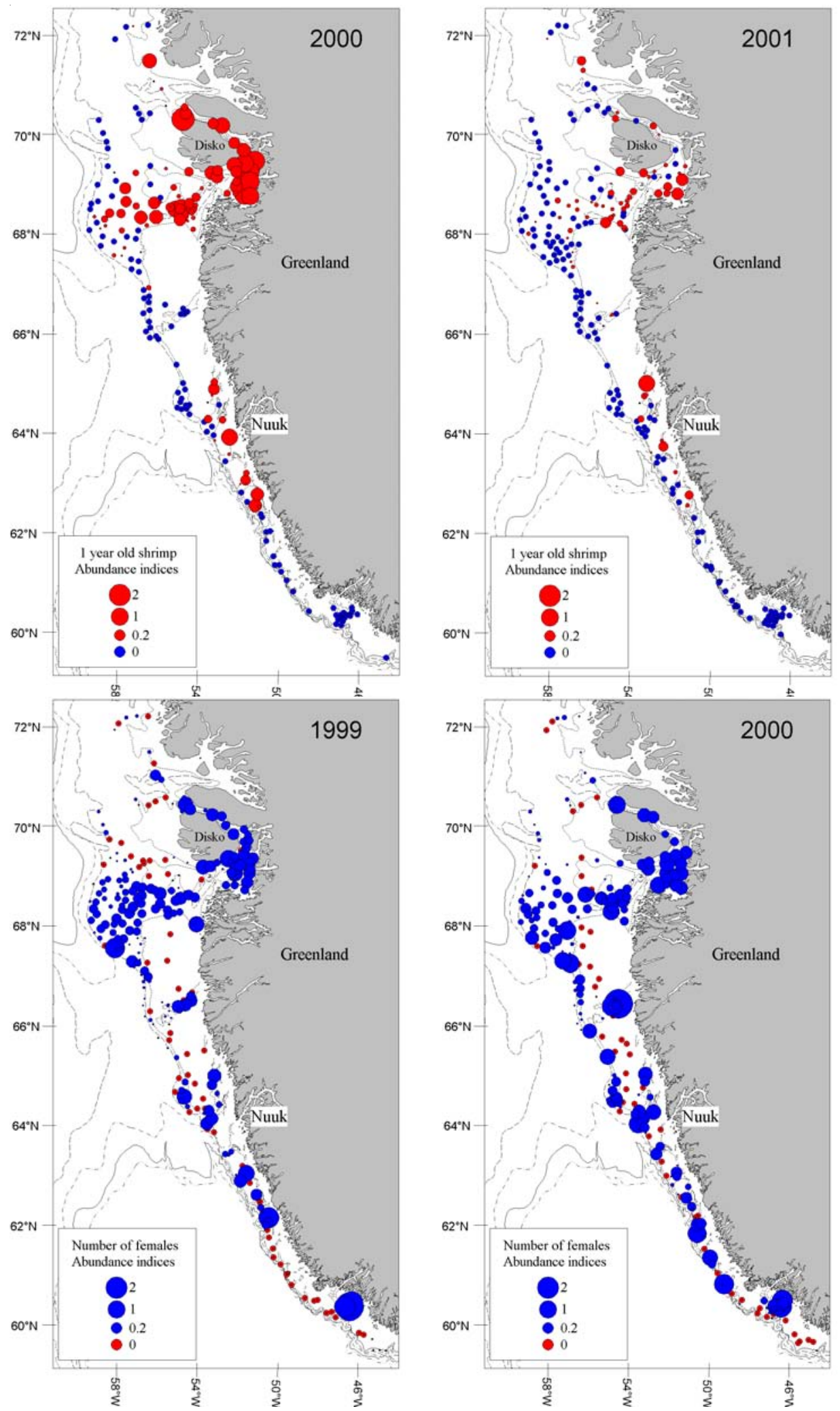

Fig. 9. Distribution and abundance indices (number $\mathrm{m}^{-2}$ ) of juveniles (age 1) in 2000 and 2001 (top panels), and females in 1999 and 2000 (bottom panels). Data of age 1 abundance indices was provided by D. M. Carlsson (Greenland Institute of Natural Resources, Nuuk, Greenland, pers. comm.) and data of female abundance indices was provided by K. Wieland (Greenland Institute of Natural Resources, Nuuk, Greenland, pers. comm.). 

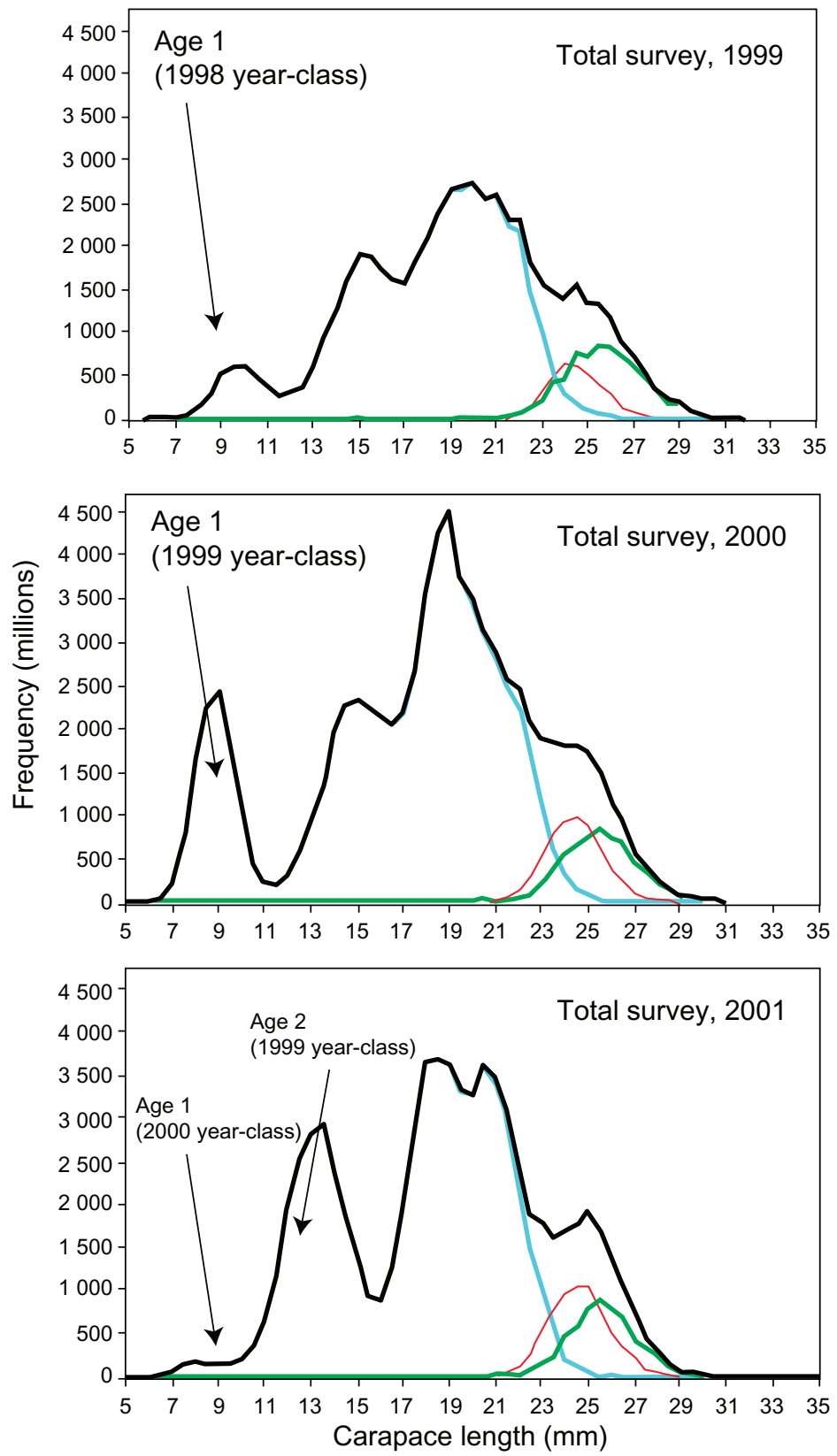

Fig. 10. Number of shrimp by length group in total survey area (offshore and Disko combined) 1999-2001. Modified from Kanneworff and Wieland, MS 2001. Blue line $=$ males, red line $=$ primiparous females, green line $=$ multiparous females, and black $=$ total .

shrimp in the Barents Sea should be considered as one stock, where female shrimp produce settling larvae in the whole distribution area. Pedersen et al. (2002) found a good agreement between the spatial distribution of modeled settled larvae and the abundance of 1 year old juveniles obtained from trawl surveys. For shrimp populations where no female stock-recruitment relationship is found particle tracking combined with biological models of pelagic larval development to settling may prove to be useful in detection of environmental impacts on recruitment success (Pedersen et al., 2002). 
In West Greenland there is large variability in year-class strength as age-1, and no female stock recruitment relationship have been found (Kanneworff and Wieland, MS 2001). For example the 1999 yearclass being at least 10 times larger than the 2000 yearclass is indicated in the size distributions of the annual West Greenland shrimp survey (Fig. 9 and 10). Differences between the two years in the environmental conditions and transport patterns of larvae during development are likely the main reason for this difference in year-class strength. Pedersen and Storm (2002) found shrimp larvae in better lipid condition in 1999 compared to 2000. The wind fields were different between the two years. In April-July 1999 wind speeds were higher and southerly winds occurred more frequently compared to 2000. According to MacKenzie (2000), resolving how larval growth rates vary with exposure to turbulence may be a suitable topic for both experimental and field evaluation.

We suggest that differences in climatological conditions between years and their effects on larval shrimp and plankton transport patterns, the physical environment (e.g. turbulence and encounter between larvae and their food), larval lipid condition indices, and larval survival should be investigated with coupled physical-biological models. Hence, future studies of shrimp recruitment in West Greenland should investigate and couple models of:

- climate change.

- physical flow field determining larval shrimp transport or retention.

- larval behaviour, e.g. vertical migrations.

- energy requirements of the shrimp larvae during development.

- food concentrations and production in the dynamic pelagic food web necessary for survival.

- effect of turbulence and prey encounter.

- match/mismatch hypothesis (Cushing, 1990).

- species interactions, e.g. to what extent do larval shrimp eat fish larvae and vice versa.

- regional nursery grounds, ontogenetic growth and movements to fishing grounds.

- top down effects e.g. effects of the shrimp fishery, increase in shrimp predators.

\section{Acknowledgements}

Thanks to Greenland Institute of Natural Resources, the crews on R/V Adolf Jensen and R/V Paamiut. Thanks to Peter Munk and Janne Elin Søreide for excellent cooperation and help during the plankton sampling in July 2000. Morten H. Nielsen was helpful during calculation of the potential energy of the water column. Dan M. Calsson was helpful providing unpubliced abundance indices of one year old juveniles. Peter Koeller (BIO), Kai Wieland and two anonymous reviewers improved earlier versions of the manuscript. The investigation was financially supported by the Danish National Research Council, project no. 9803018.

\section{References}

ANDERSON, P. J. 2000. Pandalid Shrimp as Indicators of Ecosystem Regime Shift. J. North. Atl. Fish. Sci., 27: $1-10$.

ANGER, K. and J. HARMS. 1990. Elemental (CHN) and proximate biochemical composition of decapod crustacean larvae. Comp. Biochem. Physiol., 97B(1): 69-80.

ASTTHORSSON, O. S., and A. GISLASON. 1991. Seasonal abundance and distribution of Caridea larvae in Ísafjorddeep, north-west Iceland. J. Plank. Res., 13(1): 91-102.

BERGGREEN, U., B. HANSEN, and T. KIØRBOE. 1988. Food size spectra, ingestion and growth of the copepod Acartia tonsa during development: implications for determination of copepod production. Mar. Biol., 99: 341-352.

BERKELEY, A. A. 1930. The post-embryonic development of the common Pandalids of British Columbia. Contrib. Can. Biol., 6: 79-163.

BLANTON, J. O., F. E. WERNER, A. KAPOLNAI, B.O. BLANTON, D. KNOTT, and E. L. WENNER. 1999. Wind-generated transport of fictitious passive larvae into shallow tidal estuaries. Fish. Oceanogr., 8(Suppl. 2): $210-223$.

BUCH, E. 2000. Air-Sea-Ice Conditions off Southwest Greenland, 1981-97. J. Northw. Atl. Fish. Sci., 26: 123-136.

BUCH, E., M. H. NIELSEN, and S. A. PEDERSEN. 2002. On the coupling between Climate, Hydrography and Recruitment variability of Fishery Resources off West Greenland. Proceedings of the ICES Symposium on Hydrobiological variability in the ICES area, 1990-1999 ICES J. Mar. Sci., in press.

CARLSSON and KANNEWORFF. MS 1999. Bottom temperatures and possible effect on growth and size at sex reversal of northern shrimp in West Greenland. NAFO SCR Doc., No. 110, Serial No. N4190, 6 p.

CUSHING, D. H. 1989. A difference in structure between ecosystems in strongly stratified waters and those that are only weakly stratified. J. Plankton Res., 11:1-13. 
1990. Plankton production and year-class strength in fish populations: an update of the match/mismatch hypothesis. Adv. Mar. Biol., 26: 249-293.

FRANKS, P. J. S. 1992. Sink or swim - accumulation of biomass at fronts. Mar. Ecol. Prog. Ser., 82: 1-12.

HANSEN, B., P. VERITY, T. FALKENBAURG, K. S. TANDE, F. NORRBIN. 1994. On the trophic fate of Phaeocystis pouchetii (Harriot). V. Trophic relationships between Phaeocystis and zooplankton: an assessment of methods and size dependence. J. Plankton Res., 16: 487-511.

HANSEN, B. W., T. G. NIELSEN, and H. LEVINSEN. 1999. Plankton community structure and carbon cycling on the western coast of Greenland during the stratified summer situation. III. Mesozooplankton. Aquat. Microb. Ecol. 16: 233-249.

HANSEN, A. S., T. G. NIELSEN, H. LEVINSEN, S. D. MADSEN, T. F. THINGSTAD, and B. W. HANSEN 2002. Impact of changing ice cover on pelagic productivity and food web structure in Disko Bay, West Greenland: A dynamic model approach. Deep Sea Res., (I), (in press).

HAYNES, E. 1979. Description of larvae of the Northern Shrimp, Pandalus borealis, reared in situ in Kachemak Bay, Alaska. Fish. Bull. U.S., 76: 457-465.

1985. Morphological development, identification, and biology of larvae of Pandalidae, Hippolytidae, and Crangonidae (Crustacea, Decapoda) of the northern North Pacific Ocean. Fish. Bull. U.S., 83: 253-288.

HIRCHE, H. J., and N. MUMM. 1992. Distribution of dominant copepods in the Nansen Basin, Arctic Ocean, in summer. Deep Sea Res., 39[suppl 2]: 485-505.

HORSTED, S. A. 1978. Life cycle of the shrimp, Pandalus borealis Krøyer, in Greenland waters in relation to the potential yield. ICNAF Sel. Pap., 4: 51-60.

HORSTED, S.A., and E. SMIDT. 1956. The deep sea prawn (Pandalus borealis, Kr.) in Greenland waters. Medd. Dan. Fisk.-Havunders, 1(11): 1-118.

HORSTED, S. A., P. JOHANSEN, and E. SMIDT. MS 1978. On the possible drift of shrimp larvae in the Davis Strait. ICNAF Res. Doc., No. 93, Serial No. 5309, 13 p.

HORWOOD, J., D. CUSHING, and T. WAYTT. 2000. Planktonic determination of variability and sustainability of fisheries. J. Plankton Res., 22(7): 1419-1422.

HVINGEL, C., and L. SAVARD. 1997. Northern shrimp research in the North Atlantic - state of the art and future research strategy. Nordic Council of Ministers. TemaNord, 592: 64 p.

HVINGEL, C. MS 2001. The Greenlandic Fishery for Northern Shrimp (Pandalus borealis) off West Greenland, 1970-2001. NAFO SCR Doc., No. 173, Serial No. N4518, 28 p.

ILES, D., and M. SINCLAIR. 1982. Atlantic herring: stock discreteness and abundance. Science 215: 627-633.

INCZE, L. S., and C. E. NAIMIE. 2000. Modelling the transport of lobster (Homarus americanus) larvae and postlarvae in the Gulf of Maine. Fish. Oceanogr., 9: 99-113.

INCZE, L. S., D. HERBERT, N. WOLFF, N. OAKEY, and D. DYE. 2001. Changes in copepod distributions associated with increased turbulence from wind stress. Mar. Ecol. Prog. Ser., 213: 229-240.

IVANOV, B. G. 1967. Distribution patterns of the deep-sea prawn (Pandalus borealis Kr.) in the Bering Sea and the Gulf of Alaska. Oceanology, 7: 715-721.

KANNEWORFF, P., and K. WIELAND. MS 2001. Stratifiedrandom trawl survey for northern shrimp (Pandalus borealis) in NAFO Subareas 0+1 in 2001. NAFO SCR Doc. No. 175, Serial No. N4520, 23 p.

KIØRBOE, T. 1993. Turbulence, phytoplankton cell size, and the structure of pelagic food weebs. Adv. Mar. Biol., 29: $1-72$.

KLEIN BRETLER W. C. M., H. G. FRANSZ, and S. R. GONZALEZ. 1982. Growth and development of four calanoid copepod species under experimental and natural conditions. Neth. J. Sea Res., 16: 195-207.

LILLY, G. R., D. G. PARSONS, and P. J. VEITCH. 1998. Spatial structure of northern shrimp (Pandalus borealis) off Labrador and eastern Newfoundland (northwest Atlantic). In: Proceedings of the North Pacific Symposium on Invertebrate Stock Assessment and Management. G. S. Jamieson and A. Campbell (eds.). Can. Spec. Publ. Fish. Aquat. Sci., 125: 265-271.

LOCHMANN, S. E., C.T. TAGGERT, D. A. GRIFFIN, K .R. THOMPSON, and G. L. MAILLET. 1997. Abundance and condition of larval cod (Gadus morhua) at a convergent front on Western Bank, Scotian Shelf. Can. J. Fish. Aquat. Sci., 54: 1461-1479.

LOUGH, R. G., and J. P. MANNING 2001. Tidal-front entrainment and retention of fish larvae on the southern flank of Georges Bank. Deep Sea Res. (II), 48: 631-644.

LYSY, A.Y. MS 1981. Some data on biology and distribution of larvae of deepwater shrimp Pandalus borealis Krøyer in the costal waters of West Murman. ICES C.M. Doc., No. K:8, 17 p.

1983. Distribution, abundance, and development of deepwater shrimp (Pandalus borealis) larvae in the Norweigian and Barents Seas in 1980. Ann. Biol., 38: 107-108.

MACLELLAN, D.C. 1967. The annual cycle of certain calanoid species in west Greenland. Can. J. Zool., 45: $101-115$.

MADSEN, S. D, T. G. NIELSEN, and B. W. HANSEN. 2001. Annual population development and production by Calanus finmarchicus, C. glacialis and C. hyperboreus in Disko Bay, western Greenland. Mar. Biol., 139: 75-93.

MANN, K. H., and J. R. N. LAZIER. 1996. Dynamics of marine ecosystems: biological-physical interactions in the ocean. Blackwell Science, Cambridge, 406 p.

MACKENZIE, B. R. 2000. Turbulence, larval fish ecology and fisheries recruitment: a review of field studies. Oceanologica Acta, 23: 357-375.

MUNK, P. MS 1993. Describing the distribution and abundance of small 0-group cod using ring-net sampling and echo-integration. ICES C.M. Doc., No. G:40, 13 p.

MUNK, P., P. O. LARSSON, D. DANIELSEN, and E. MOKSNESS. 1995. Larval and small juvenile cod (Gadus morhua) concentrated in the highly productive areas of a shelf break front. Mar. Ecol. Prog. Ser., 125: $21-30$. 
NIELSEN, T. G., and B. W. HANSEN. 1995. Plankton community structure and carbon cycling on the western coast of Greenland during and after the sedimentation of a diatom bloom. Mar. Ecol. Prog. Ser., 125: 239-257.

NIELSEN, T. G., and B.W. HANSEN.1999. Plankton community structure and carbon cycling on the western coast of Greenland during the stratified summer situation. I. Hydrography, phytoplankton and bacterioplankton. Aquat. Microb. Ecol., 16: 205-216.

OUELLET, P., LEFAIVRE, D., and V. KOUTITONSKY. 1990. Distribution of shrimp (Pandalus borealis) larvae and hydrographic pattern in the northern Gulf of St. Lawrence. Can. J. Fish. Aquat. Sci., 47: 2068-2078.

OUELLET, P., and D. LEFAIVRE. 1994. Vertical distribution of northern shrimp (Pandalus borealis) larvae in the Gulf of St. Lawrence; Implications for trophic interactions and transport. Can. J. Fish. Aquat. Sci., 51: 123-132.

OUELLET, P., TAGGART, C. T., and K.T. FRANK. 1995. Early growth, lipid composition, and survival expectations of shrimp Pandalus borealis larvae in the northern Gulf of St. Lawrence. Mar. Ecol. Prog. Ser., 126: 163-175.

PARSONS, D. G., and E. B. COLBOURNE. 2000. Forecasting Fishery Performance for Northern Shrimp (Pandalus borealis) on the Labrador Shelf (NAFO Divisions 2HJ). J. Northw. Atl. Fish. Sci., 27: 11-20.

PEDERSEN F. B. 1986. Environmental hydraulics: stratified flows. Springer-Verlag, Berlin.

PEDERSEN L., H. M. JENSEN, A. BURMEISTER, B. W. HANSEN. 1999. The significance of food web structure for the condition and tracer lipid content og juvenile snail fish (Pisces: Liparis spp.) along $65-72 \mathrm{~N}$ off West Greenland. J. Plank. Res., 21: 1593-1611.

PEDERSEN, O. P., M. ASCHAN, T. RASMUSSEN, K. S. TANDE, and D. SLAGSTAD. 2002. Larval dispersal and mother populations of Pandalus borealis investigated by a Lagrangian tracking model. Fish. Res., Accepted.

PEDERSEN, S. A. 1998. Distribution and lipid composition of Pandalus shrimp larvae in relation to hydrography in West Greenland waters. J. Northw. Atl. Fish. Sci., 24: 39-60.

PEDERSEN, S. A., and E. L. B. SMIDT. 2000. Zooplankton distribution and abundance in West Greenland waters, 1950-1984. J. Northw. Atl. Fish. Sci., 26: 45-102.

PEDERSEN, S. A., and J. RICE. 2002. Dynamics of fish larvae, zooplankton, and hydrographical characteristics in the West Greenland Large Marine Ecosystem 19501984. In: Large Marine Ecosystems of the North Atlantic. Changing States and Sustainability. K. S. Shermann, and H.-R. Skjoldal (eds). Chapter 5. Elsevier Science (www.elsevier.com/locate/isbn/0444510117).

PEDERSEN, S.A., and L. STORM. 2002. Northern shrimp (Pandalus borealis) recruitment in West Greenland waters. Part II. Lipid classes and fatty acids in Pandalus shrimp larvae: implications for survival expectations and trophic relationships. J. Northw. Atl. Fish. Sci., 30: 47-60 (this volume).

PIKE, R. B., and D. I. WILLIAMSON. 1964. The larvae of some species of Pandalidae (Decapoda). Crustaceana, 6: $265-284$.
POULSEN, L. K., and N. REUSS. 2002. The plankton community on Sukkertop and Fylla Banks off West Greenland in a spring bloom and post-bloom period. Hydrography, phytoplankton and protozooplankton. Ophelia, 56(2): 69-85.

RASMUSSEN, T. MS 1993. Temperature dependent development, growth, and mortality of Northern shrimp larvae (Pandalus borealis KRØYER 1838) in the laboratory. Master of Science thesis (Cand. scient.) University of Troms $\varnothing$, Norway. $74 \mathrm{p}+$ appendix. (in Norwegian).

RASMUSSEN, T. and K. S. TANDE. 1995. Temperaturedependent development, growth and mortality in larvae of the deep-water prawn Pandalus borealis reared in the laboratory. Mar. Ecol. Prog. Ser. 118[1-3]: 149-157.

RASMUSSEN, T., M. ASCHAN, and J. S. CHRISTIANSEN. MS 2000. The implementation of laboratory studies to recruitment modelling - a brief review of experimental procedures. ICES C.M. Doc., No. R:07. 16 p.

REISS, C. S., G. PANTELEEV, C. T. TAGGART, J. SHENG, and B. DeYOUNG. 2000. Obeservation on larval fish transport and retention on the Scotian Shelf in relation to geostrophic circulation. Fish. Oceanogr., 9(3): 195-213.

SABATINI, M., and T. KIØRBOE. 1995. Egg production, growth and development of cyclopoid copepod Oithona similis. J. Plank. Res., 16: 1329-1351.

SAVENKOFF, C., L. SAINT-AMAND, P. OUELLET, and T. T. PACKARD. MS 1995. An index of respiratory effiency in the shrimp Pandalus borealis (Krøyer) larvae. Can. Tech. Rep. Fish. Aquat. Sci., 2072: vi+26 p.

SAS, 1985. SAS User's Guide: Basics/Statistics Version 5. SAS Institute Inc., Raleigh, North Carolina.

SCHULTZE, K., and K. ANGER. 1997. Larval growth patterns in the aesop shrimp Pandalus montagui. Journal of Crustacean Biology, 17(3): 472-479.

SHUMWAY, S. E., H. C. PERKINS, D. F. SHICK, and A. P. STICKNEY. 1985. Synopsis of biological data on the pink shrimp, Pandalus borealis Krøyer, 1838. NOAA Tech. Rep., NMFS 30, (FAO Fish. Synopsis, No. 144), 57 p.

SIEGSTAD, H. MS 2000. Preliminary Assessment of Shrimp (Pandalus borealis) in Davis Strait, 2000 (Subareas 0+1). NAFO SCR Doc., No. 84, Serial No. N4341, 22 p.

SINCLAIR, M. 1988. Marine Populations. An Essay on Population Regulation and Speciation. University of Washington Press, Seattle, WA, 252 p.

SMIDT, E. L. B. 1979. Annual cycles of primary production and of zooplankton at Southwest Greenland. Meddelelser om Gronland, Bioscience, 1: 53 p.

SMITH, P. E., and S. L. RICHARDSON. 1977. Standard techniques for pelagic fish egg and larvae surveys. FAO Fish. Tech. Pap., 175, 100 p.

STICKNEY, A. P., and H. C. PERKINS. 1981. Observations on the food of the larvae of the northern shrimp, Pandalus borealis Kröyer (Decapoda, Caridea). Crustaceana, 40(1): 36-49.

SQUIRES, H. J. 1993. Decapod crustacean larvae from Ungava Bay. J. Northw. Atl. Fish. Sci., 15: 1-157.

TAGGART, C. T., K. F. DRINKWATER, K. T. FRANK, J. MCRUER, and P. LAROUCHE. 1989. Larval fish, 
zooplankton community structure, and physical dynamics at tidal front. In: Early Life History of Fish, J. H. S. Blaxter, J. C. Gamble, H. von Westernhagen, (eds). 3. ICES Symp. on the Early Life History of Fish, Bergen (Norway), 3-5 Oct 1988. ICES Rapp. Proc.Verb., 191: 184-194.

TANDE, K. S., T. RASMUSSEN, and G. PEDERSEN. 1994. Thermal Increase Enhancement: a possible link between recruitment and climate in high latitude environments. ICES Mar. Sci. Sym., 198: 502-509.
WERNER, F. E., B. R. MACKENZIE, R. I. PERRY, R. G. LOUGH, C. E. NAIMIE, B. O. BLANTON, and J. A. QUINLAN. 2001. Larval trophodynamics, turbulence, and drift on Georges Bank: A sensitivity analysis of cod and haddock. Sci. Mar., 65: 99-115.

WIELAND, K. and D. M. CARLSSON. MS 2001. Geographical distribution and mean size of different life stages of northern shrimp (Pandalus borealis) off West Greenland. NAFO SCR Doc., No. 178, Serial No. N4567, $15 \mathrm{p}$. 
Appendix 1: Figures shows Pandalus sp. Abundance
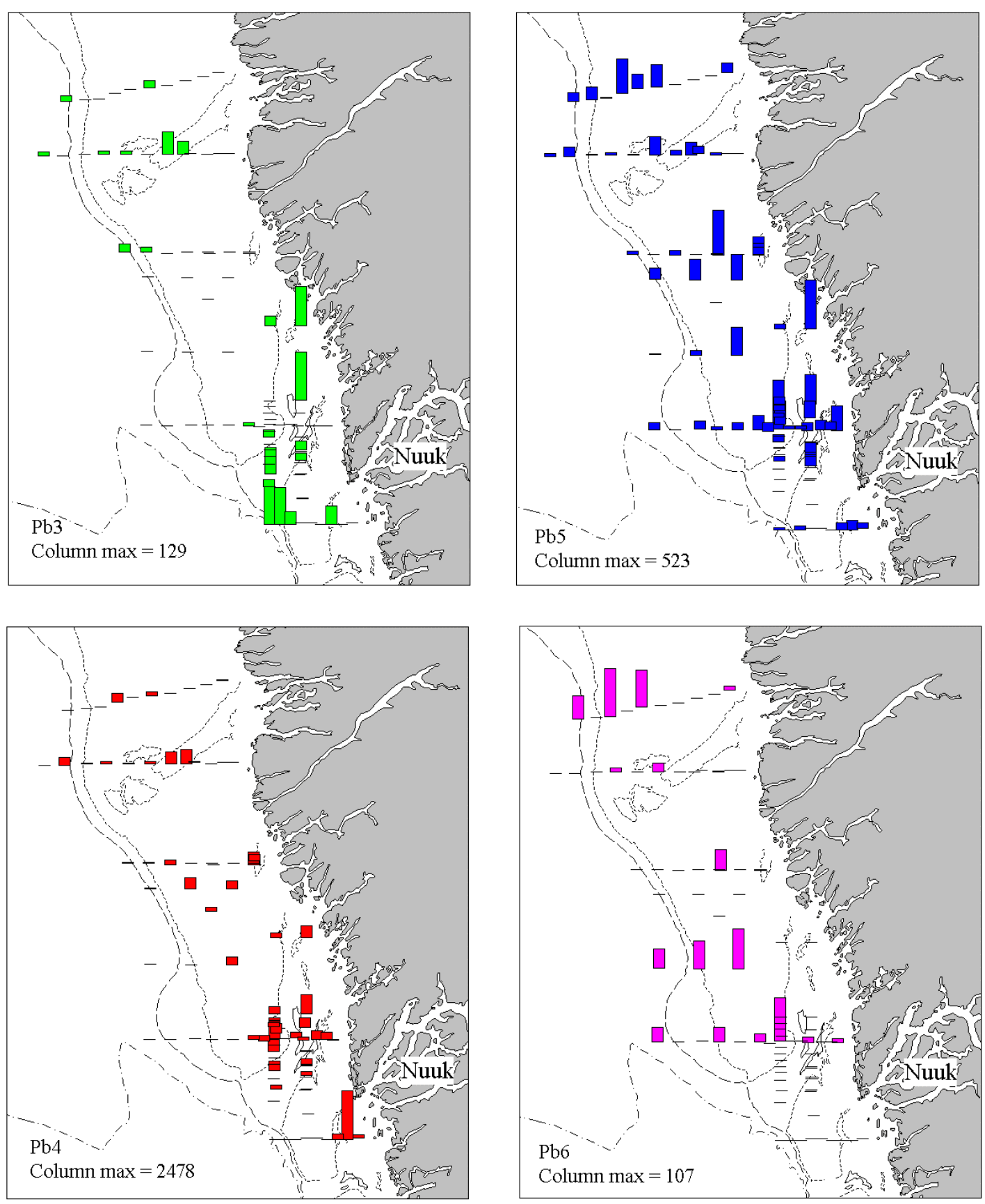

Fig. 1. Abundance indices of P. borealis larvae (number per $100 \mathrm{~m}^{2}$ ) zoeal stage 3 to 6 ( $\mathrm{Pb} 3$ to $\mathrm{Pb} 6$ ), July 2000 . 

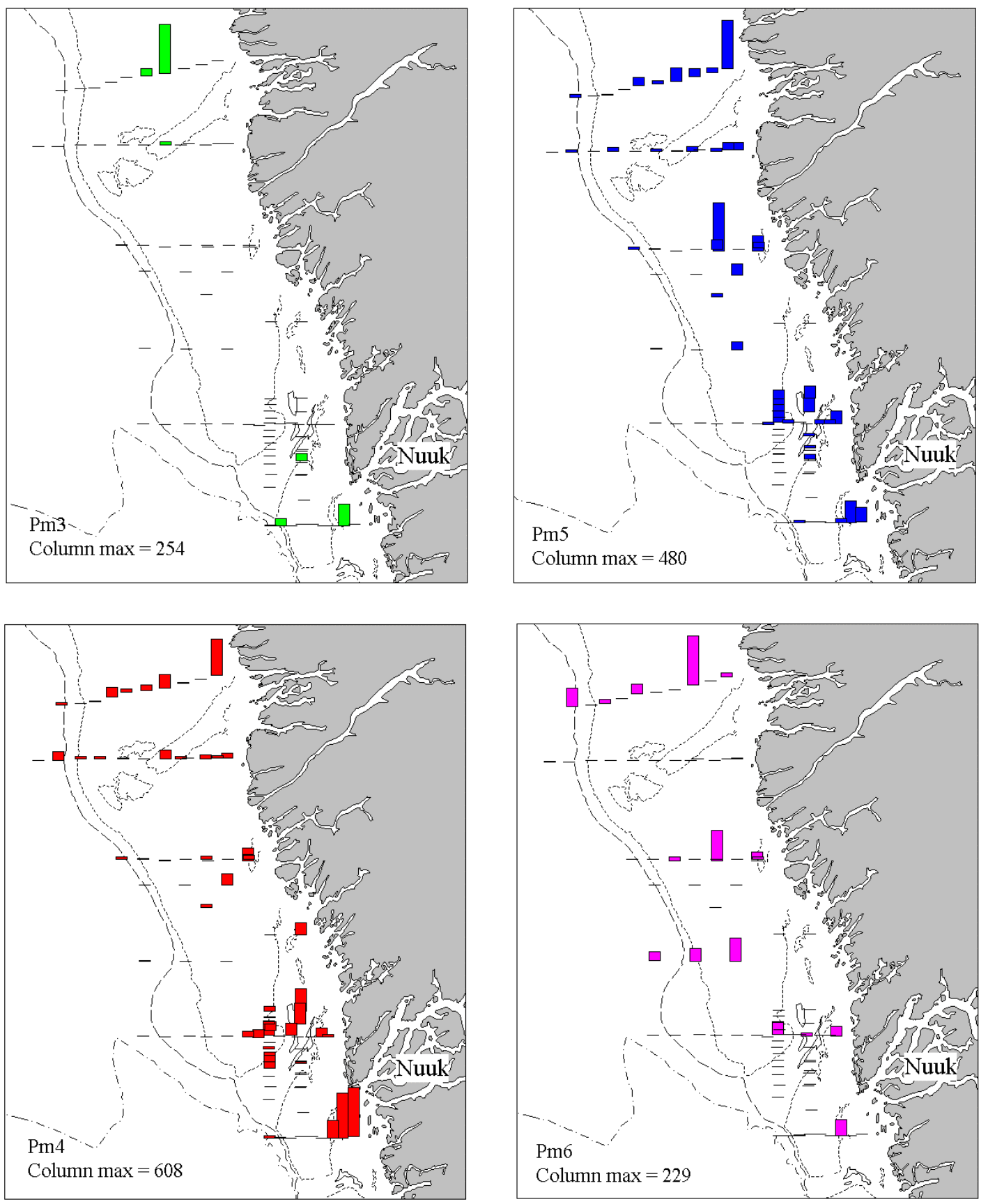

Fig. 2. Abundance indices of P. montagui larvae (number per $100 \mathrm{~m}^{2}$ ) zoeal stage 3 to 6 (Pm3 to Pm6), July 2000. 